\title{
Trump vs. China? Tariffs under Section 232 of the Trade Expansion Act of 1962 Revisited
}

\author{
Eric Hanada
}

(D) https://orcid.org/0000-0001-9257-9635

\begin{abstract}
This study challenges the common belief that the 'Trump tariffs' are protectionist or a deliberate attack on China, the USA's economic rival. By focusing specifically on Section 232 of the Trade Expansion Act of 1962 and equating its use to Section 301 of the Trade Act of 1974, this study instead demonstrates how the U.S. administration is actively repurposing protectionist laws to function as unilateral enforcement tools. Thus, this study argues that the tariffs enacted on steel and aluminium in 2018 under the guise of national security are not meant to protect the domestic market or to hurt the Chinese, but rather to 'protect' the ability of U.S. businesses to make profits abroad. By contrasting the justification for the tariffs to factual application, China is not identified as a target but rather as a convenient fig leaf. The article goes into further detail to demonstrate how the U.S. (ab)uses these tariffs during negotiations with South Korea, Japan, and other nations and finds multiple examples of how others have been affected significantly more than China. Here, the article describes how U.S. officials have mastered the art of simultaneously creating leverage, exchanging it for concessions, and keeping it.
\end{abstract}

Keywords: Trade war, United States, China, tariffs, Section 232

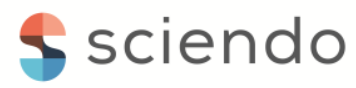

Hanada, Eric. 2020. "Trump vs. China? Tariffs under Section 232 of the Trade Expansion Act of 1962 Revisited." Vienna Journal of East Asian Studies, 12, pp. 207-251.

https://doi.org/10.2478/vjeas-2020-0008

Submitted: 03.05.2020, accepted: 17.07.2020

This work is licensed under the Creative Commons Attribution 4.0 International License. http://creativecommons.org/licenses/by/4.0/ 


\section{Introduction}

The tariffs enacted by the United States (U.S.) against China since 2018 were cause for much controversy, but their supposed intent was certain: they were protective tools. The U.S.' sudden and unprecedented turn to protectionism took many by surprise (Fajgelbaum et al. 2019: 1), particularly after driving globalisation for decades (Sheng, Zhao, and Zhao 2019: 137). The new style was thus described as a breach with previous administrations (Breuss and Christen 2019: 9), which manifested most noticeably in hostile rhetoric and action (Meunier 2019: 132).

This study challenges this interpretation of recent U.S.-American trade politics. By following up on my Master's thesis, "The Economic Rivalry between Japan and the U.S. in the 1980s, and China and the U.S. since the 1990s" (Hanada 2019), it specifically aims to reopen the discussion on how the steel and aluminium tariffs enacted under section 232 of the Trade Expansion Act of 1962 in 2018 are being utilised. I argue that they served to erect artificial barriers which were then turned into bargaining counters to be exchanged for concessions on trade. This claim based on the original study (Hanada 2019: 207) is further developed in this article by briefly reviewing the current discourse (and its shortcomings), past tariffs use, and applicable laws. This is then followed by an introduction of methods and test cases.

\section{A Protectionist Frenzy?}

In recent years, economists argued that protectionist waves (particularly those related to steel) like that of 2018 can be observed throughout history and stressed that consequences were always harmful (Lee 2019: 488; Williams et al. 2019: ii). Given the assumed familiarity with the measure at hand, there was little doubt that the official justifications pertaining to national security were a smokescreen meant to obfuscate protectionism and the "[...] violation of U.S. commitments at the WTO [World Trade Organisation] [...]" (Williams et al. 2019: 45; see also Lee 2019: 488).

The debate seems particularly focused on contemporary U.S. president Donald Trump (b. 1946). Due to his stark rhetoric (Irwin 2017: 687), Mr. Trump is frequently branded a protectionist (e.g., Swanson and Ewing 2018) and his inaugural speech propagating an "America first" trade policy and other similar statements certainly made him the symbol of modern protectionism (e.g., Meunier 2019: 139; Irwin 2017: 686). He was accused of spinning "[...] an increasingly complex web of trade protection" and "[his] 2018 tariff spree [...]" (Bown and Zhang 2019) continued as recently as January 24, 2020, which was just the latest of his "[...] acts of protection" (Bown 2020). Consequently, the tariffs enacted since 2018 quickly became known as the "Trump tariffs" or "Trump's tariffs" (Bown 2019: 4) —a term that is now commonly used. 
Such a simplification, however, poses two major issues: first, the notion that "the Trump tariffs" are in fact protectionist is generally accepted, probably because tariffs and protectionism have become two intertwined terms that few would second-guess. ${ }^{1}$ Alternative opinions exist but are usually dismissed swiftly. Second, and equally important, terms like "the Trump tariffs" obscure the fact that these measures are not uniform but based on multiple laws with specific aims and differing procedures behind them. Thus, it is hardly surprising to find that some scholars mislabel tariffs enacted under section 301 of the Trade Act of 1974 as protectionist (e.g., Breuss and Christen 2019: 2-3) or neglect differences altogether (e.g., Sposi and Virdi 2018: 3).

\section{Use of Tariffs}

Tariffs are income generating taxes on imports with a distributive impact, meaning they generate winners and losers (Mavroidis 2016: 135). Scenarios with advantageous applications (despite retaliation) have been suggested (Johnson 1954: 153), yet most economists agree that tariffs primarily generate loss, which makes them inadvisable (Williams et al. 2019: ii).

Tariffs can be applied in multiple ways. Raymond Riezman (1982: 21) describes four primary applications, namely use:

- in cases of market imperfections (when free trade becomes undesirable or unobtainable);

- temporarily during a sluggish adjustment of the world economy towards free trade;

- for political reasons like nationalism;

- to protect either a nation's welfare or a specific interest group.

These general scenarios are found in concrete applications, most of which the U.S. was accused of during the current dispute.

The most prominent manifestation is certainly industry protection. Most commentators focus on this possibility by referencing Mr. Trump's "make America great again" speech. It is believed that the U.S. shields its industries with tariffs until better protection can be negotiated (e.g., Sheng, Zhao, and Zhao 2019: 138). The White House fosters such narratives by attributing the steel industry's good health to current tariffs (WH 2018a). Yet the usual indicator for protectionism - such as observable correlation between protected industries and presidential campaign contributions-is missing in contemporary cases (Fajgelbaum et al. 2019: 7).

Another popular argument focuses on voter pandering and how decisiveness can increase a politician's chances for re-election. P. D. Fajgelbaum et al. (2019: 3) show

\footnotetext{
${ }^{1}$ The experience with the Smoot-Hawley tariffs is likely shaping the discourse as described in The Economic Rivalry between Japan and the U.S. in the 1980s, and China and the U.S. since the 1990s (Hanada 2019: 12-13).
} 
that "[...] import protection was biased toward products made in electorally competitive counties [...] suggesting a potential ex ante electoral rationale for the pattern of tariffs increases." Tariffs are generally popular with voters because costs are distributed and negative effects are thus not individually felt. Although only the rich benefit from a tariff war (Mayer and Riezman 1990: 169-171), promises to use tariffs for job protection ( $\mathrm{Li}, \mathrm{He}$, and Lin 2018: 1561) can certainly be attractive. The Smoot-Hawley tariffs of the 1930s, which became a prevalent analogy for the "Trump tariffs," have been attributed to voter pandering (Irwin 2011: 29, 65-66, 93). As Mr. Trump is allegedly following in Herbert Hoover's footsteps (Irwin 2017: 686), he may have similar goals in mind.

The income-generating aspect of tariffs (Mavroidis 2016: 135, 163) was suggested on occasion (e.g., Yu 2018: 147) but seems unlikely in this case. Such tariffs would need to be put on products with low import demand elasticity to be effective (Broda, Limão, and Weinstein 2006: 27), which is not the case for steel and aluminium (Ghodsi, Grübler, and Stehrer 2016: 18).

A terms of trade effect motive seems possible given countless complaints from U.S. officials about the unacceptable trade deficit with China (e.g., Sun and Wang 2018: 548). It has been noted that governments pursuing such an objective generally do not emphasise social welfare expansion (Broda, Limão, and Weinstein 2006: 7), which is likely the case here. However, Fajgelbaum et al. (2019: 6-7) dismiss this proposition due to the generally homogeneous pattern of tariffs, which under a terms of trade use would see more variety across sectors.

A new usage possibility intended to stifle China's technological progress was also suggested (e.g., Sun and Wang 2018: 549). This seems somewhat plausible given that in many cases tariffs were applied to industries important to the Made in China 2025 (MIC 2025²) initiative (Lu 2018: 91-92).

In his latest book, economic historian Douglas A. Irwin describes three principle phases of U.S. trade policy, each with distinct aims These are summarised as the "three Rs:" "[...] raising revenue for the government [...], restricting imports to protect domestic producers [...], and concluding reciprocity agreements to [...] expand exports" (Irwin 2017: 2). Since 1934, the principle objective of U.S. trade policy has been the opening of foreign markets to U.S. businesses by negotiating a mutual reduction of import barriers (Irwin 2017: 8). Protectionism is said to be limited to agriculture and usually applied via Anti-Dumping (AD) or Countervailing Duties (CVD) (Irwin 2017: 585-588).

Irwin's deduction is mostly consistent with what the precursor to this study ascertained, namely that the U.S. is leveraging market access in negotiations (Hanada 2019:

\footnotetext{
${ }^{2}$ MIC 2025 is an initiative by the Chinese government to move production into more innovative and high-value-added fields.
} 
205-206). Yet contemporary scholars and journalists seemingly fail to recognise ${ }^{3}$ the U.S.' habit of artificially erecting barriers only to negotiate them down (Hanada 2019: 207). This is odd because the Trump administration has stated this tactic openly on several occasions (e.g., WH 2018a), arguing that:

[W] 're using tariffs very successfully to negotiate [because] we are the one that [other countries] come and want to take from. [...] And that gives us a tremendous advantage in negotiating that we never used before with past administrations $\left[{ }^{4}\right]$. [...] Because of the power of tariffs and the power that we have with tariffs, we, in many cases, won't even have to use them (WH 2018a)

The idea of raising barriers "[...] to serve as bargaining counters [...]" (Johnson 1952: 28) is quite old and simple: "[...] duties will be bound following reciprocal negotiations, where trading nations give a tariff promise in exchange for a tariff promise they receive" (Mavroidis 2016: 145). Countries with market power are in a better position, particularly in the absence of a regulatory body like the WTO (Broda, Limão, and Weinstein 2006: 4). It is strongly suggested that market power would become the determining factor in tariff policy where the WTO lacks authority (Broda, Limão, and Weinstein 2006: 33), which is the case with certain U.S. laws.

\section{Section 232 and Other Relevant Laws}

The nature of the "Trump tariffs" and the purpose and function of laws under which they have been applied is oftentimes obscured. Yet:

[I]t is important to understand that there are distinct types of tariffs, implemented for entirely different reasons, under specific statutory authorities under U.S. law-each holding vastly different implications for the global trade system (Olson 2018).

Fortunately, Brock R. Williams et al. (2019) provide a cogent summary of relevant laws, their intent, and applications (see also figure 1):

Section 232 of the Trade Expansion Act of 1962. Allows the President to take action to adjust imports if the U.S. Department of Commerce finds certain products imported into the United States in such quantities or under such circumstances as to threaten to impair U.S. national security (19 U.S.C. §1862) (Williams et al. 2019: 2; emphasis original).

Section 301 of the Trade Act of 1974. Allows the United States Trade Representative (USTR), at the direction of the President, to suspend trade agreement concessions or impose import re-

\footnotetext{
${ }^{3}$ A few acknowledge the existence of such tactics (e.g., Sun and Wang 2018: 556-557; Williams et al. 2019: 6; The Economist 2018). Some also notice striking similarities to Japan and the U.S. during the 1980s (Lester, Manak, and Kim 2019).

${ }^{4}$ This statement is factually incorrect since this negotiation tactic has been part of U.S. trade policy for decades (see Bhagwati 1991; Bayard and Elliott 1994; Hanada 2019).
} 
strictions if it determines an act, policy, or practice of a foreign country violates, or is inconsistent with, the provisions of, or otherwise denies benefits to the United States under, any trade agreement or is unjustifiable and burdens or restricts U.S. commerce (19 U.S.C. §2411-2420) (Williams et al. 2019: 2; emphasis original).

Henceforth, both sections will be referred to as Section 232 and Section 301 respectively.

This study predominantly focuses on Section 232 to limit its scope and acquire more relevant results. Section 201 of the Trade Act of 1974 (see figure 1) was neglected because the law became mostly redundant due to the difficulty of proving a case (Irwin 2017: 588). Section 301 will only be used as a reference because it is arguably utilised as intended - not for protection but for unilateral market opening purposes. Furthermore, it is assumed that if the (officially) protectionist Section 232 is misused as a unilateral enforcement tool (as argued below), it is highly doubtful that Section 301 would be used in a protectionist manner.

Section 232 can be found in the trade expansion programme under U.S. custom duty law (USC 2020a), the stated purpose for which is "[...] to stimulate the economic growth of the United States and maintain and enlarge foreign markets for the products of United States agriculture, industry, mining, and commerce [...]" (USC 2020a). Like Section 301, Section 232 allows for negotiation of agreements to resolve issues but limits the scope of such agreements to restricting exports to the U.S. market (USC 2020a). Furthermore, "[...] the law does not permit the President to impose measures not directly related to imports relief [...]" (Leibowitz 2017: 4).

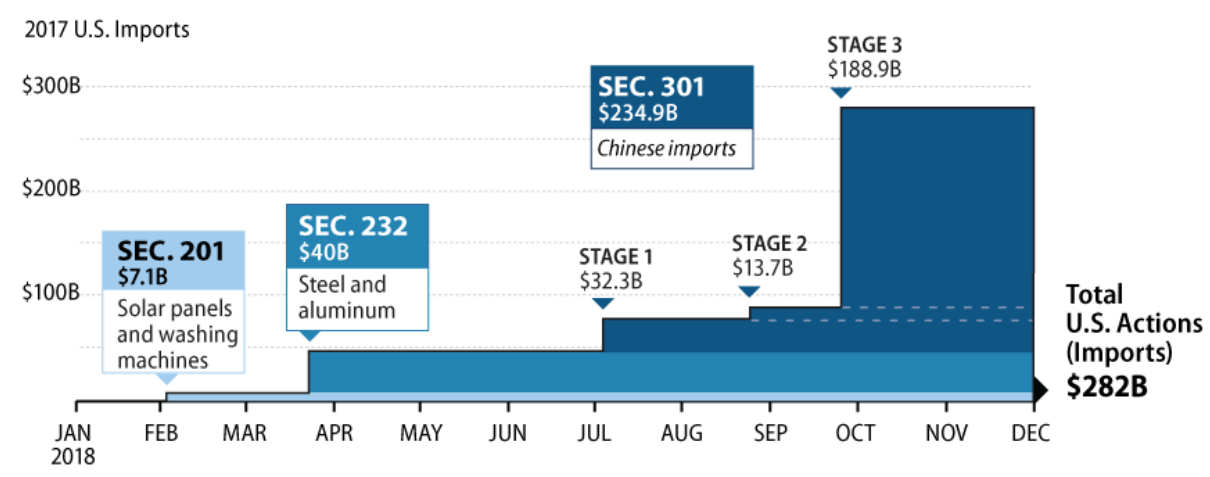

Figure 1: Tariff overview (as of December 2018). Source: Williams et al. (2019: 3).

Thirty-one investigations have been conducted under Section 232 since 1962; thirteen cases were self-initiated (three under Mr. Trump), and eleven cases were found 
potentially to impair national security. U.S. Presidents acted eight ${ }^{5}$ times (Fefer et al. 2019: 3), the last time in 1986 (Fefer and Jones 2019: 1).

\section{Challenging Common Assumptions}

As shown above, ignorance regarding methods and reasons raises four issues: laws can get confused, which may lead to claims of protectionism; false association with separate conflicts (China); and an overwhelming focus on individual actors.

Addressing the last issue first, there appears to be a strong focus on Mr. Trump and his statements. This can encourage faulty conclusions as the administration's actions might be pinned to Mr. Trump's personal views (e.g., Rashish 2018: 3). It may further obfuscate actual protectionism by the U.S., which is almost exclusively done through AD and CVD (Bown 2020). It also obscures the fact that pro-protection sentiments can be found across party lines and institutions (e.g., Franken 2017). Most importantly, it disregards the past and presents an inaccurate picture of U.S. trade policy. As Irwin states, "[i]f one focuses only on the immediate conflict, one might miss the longer-term stability" (Irwin 2017: 689-690). This essentially reflects the underlying theme of the original study (Hanada 2019), hence why it is unnecessary to pursue this subject any further.

This article will thus focus on the remaining issues. All three are arguably interlinked as a flawed understanding of a conflict leads to wrong conclusions about it. This can be observed when visible manifestations of trade law (like tariffs) are mixedup. Section 301 is anything but protectionist, but its long and chilling legacy as a unilateral enforcement tool meant to pry open markets seems mostly forgotten. Instead, it is now lumped-in with the officially protectionist Section 232 and labelled accordingly (e.g., Breuss and Christen 2019: 13).

Based on previous results (Hanada 2019: 207), official statements (WH 2018a), and secondary research (Irwin 2017: 8), this article claims the opposite. Section 301 was not turned protectionist, but rather Section 232 was aligned more closely with Section 301 to become a unilateral tool for opening markets. It is used to erect barriers which are then negotiated down. This strategy works because it is assumed that costs associated with making unilateral concessions are still lower than losing access to the U.S. market altogether (see Bayard and Elliott 1994: 80). A positive correlation between market share and susceptibility to such measures (or threats thereof) is consequently expected. This primary function of Section 301 will thus become the base for the analytical framework explained further below.

This strategy was already at the centre of a legal challenge in 2018. A Swiss-Russian company sued the president, arguing the tariffs under Section 232 were an abuse

\footnotetext{
${ }^{5}$ Other articles from the same authors mention nine but it is not clear what they are referring to (see Fefer and Jones 2019: 2).
} 
of power because tariffs were not intended for protection but to negotiate concessions unrelated to steel imports (Restani 2018: 19). The company referred to the United States-Mexico-Canada Agreement (USMCA) negotiations as evidence, which the court considered "[in]sufficient on their own to underpin a credible case [...]" (Restani 2018: 22-23), and consequently denied the plaintiff's motion for preliminary injunction (Restani 2018: 25). Although the case was dismissed, this article will provide additional evidence either in support of the company's arguments or the court's decision. As the issue is unlikely to disappear any time soon, these results may become helpful if similar legal challenges arise.

I considered examining tariff use both for voter pandering and to stifle China's economic progress. However, the former seemed sufficiently covered (e.g., Fajgelbaum et al. 2019), and the latter is mostly associated with the tariffs under Section 301 (Hanada 2019: 122), and is thus not of much relevance.

This article further argues that the U.S.' current actions are puzzling because they are believed to be protectionist, even when they are not. This might be attributed to many commentators being economists; they may not see value in tariffs beyond immediate economic rationales (like protection). Here, a different perspective from the greater field of International Relations can offer a new perspective. When reversing the argument (as suggested above), it suddenly becomes possible to explain " [...] what the Trump administration's ultimate goal actually is when it comes to automotive tariffs" (Schneider-Petsinger 2019: 10). It also explains the surprising "[...] nationalist, protectionist turn of a faction of the Republican Party [...]” (Meunier 2019: 133), which apparently caught many off-guard. Moreover, common assumptions regarding China are disputed as the U.S. might not aim to reduce imports as is often argued (Lu 2018: 100), but rather intends to expand exports (Hanada 2019: 127).

Lastly, by being able to distinguish between applicable laws, it also becomes evident that multiple conflicts are summarised by the misleading label "the Trump tariffs" (e.g., Breuss and Christen 2019: 7; Bown 2019: 4). This matters because although steel and aluminium overcapacity in China served as justification to erect tariffs under Section 232, unlike the Section 301 tariffs from 2018, these are unlikely to target China specifically due to their dispersion effects. This also highlights why Section 232 was a mere side note in the original study (Hanada 2019: 25).

To summarise, this study expects to find:

- Section 232 is not used for protection but to erect artificial barriers to serve as bargaining counters (akin to Section 301);

- a positive correlation between the impact of (potential) tariffs upon parties and willingness to make concessions;

- China is not the main target.

As explained, it is assumed that much of the confusion about the Section 232 tariffs stems primarily from the misuse of the law. Consequently, an analysis would need to 
account for the gap between what is legally argued and what is done. A complementary research question to address this point and further examine the claims made above is: how does the justification for the enactment of tariffs under Section 232 of the Trade Expansion Act of 1962 differ from their factual utilisation?

\section{Theoretical Considerations and Methodology}

This spin-off article will predominantly rely on the same logic applied to the original (see Hanada 2019: 18-20) and thus may reconfirm or disprove earlier results by providing further evidence. Section 232 was previously neglected for not meeting the definition of a hostile economic measure ${ }^{6}$ due to its broad effect (Hanada 2019: 25). Consequently, the adapted methodology for this article is not concerned with identifying measures in general, but rather with identifying the intent behind one specified measure.

As explained above, this article focuses on the template provided by Section 301 . This approach was chosen because the most striking conclusion drawn from the original study exposed how U.S. trade policy specialised in leveraging the home market during negotiations (Hanada 2019: 205-206). Such leverage is artificially created by different means (tariffs, quotas, threats etc.) but always with the intention of exchanges for real concessions (Hanada 2019: 207). This essentially describes how Section 301 was utilised in the past (e.g., Bhagwati 1991: 5, 16, 35).

The continual appearance of terms like "relative gains" and "constant sum" as well as the focus on steel would support an analysis based on neorealism; in trade, "[...] bargaining positions [of states] will be shaped by their interests in improving their relative power positions" (Zeng 2004: 27). Yet neorealism is unable to explain why states would willingly trade their own security for other concessions when national survival could be at stake. This is particularly relevant in this case-Section 232 is the national security clause, and steel (special due to its military importance) is involved (Conybeare 1987: 214). Thus, in a neorealist world, it is unlikely that the U.S. would risk depending on foreign steel suppliers for economic concessions (Waltz 2000: 15; Mearsheimer 1995: 11-12), which-as this article is going to show-happened on multiple occasions.

Arguably, economic concessions could be more beneficial to the military than potential losses on steel given that new export opportunities would allow for production to expand due to economies of scale. This would lead to increased income and consequently an expanded military. Yet the way the national security clause was triggered assumes a fundamental threat to the U.S.' ability to maintain military operations, which certainly is a non-negotiable risk to neorealists (see Mearsheimer 1995: 10-11).

\footnotetext{
${ }^{6}$ A "hostile economic measure" is a targeted action towards a friendly nation which hurts their economy and benefits one's own.
} 
Consequently, this article follows more of a neomercantilist logic, which similarly places high importance on power in an assumed zero-sum world where a nation must generate relative gains in order to preserve its military advantage. Yet neomercantilism equates national security with safeguarding national economic interest, which means a 'trade' as suggested above is imaginable (see Gilpin 1987: 31-32). It is further assumed that states, particularly hegemons, do not have much to gain from free trade, giving them an incentive to benefit from maximising income through some sort of trade measures (Conybeare 1987: 60-61; Gilpin 1987: 42-43, 77, 115). Consequently, this study will approach the subject under the assumption that:

a) the U.S.' primary objective is to maximise economic gains; and

b) the U.S. erects barriers to 'trade' for such gains.

This article does not claim that all concessions directly result from swaps for tariff relief. It is not possible to conclude with certainty that concession A would not exist without tariff $\mathrm{X}$ as tariffs are just one of many tools available to pressure an opponent. It is rather suggested that tariffs used in a non-protectionist fashion are one important factor among others.

An approach like this can be prone to generating false correlations and may only provide weak evidence (as argued during the court case) (Restani 2018 : 22-23). Consequently, only 'trades' with clear links to actions under Section 232 will be acknowledged. Such a link must be directly established by officials to be considered viable (including official statements, paragraphs within agreements etc.). Therefore, this study will rely predominantly on official government documents and press releases. Given the Section 232 report on automobiles was not released as of February 2020, it could not be included in its entirety. This study will thus mainly focus on steel and aluminium and only refer to the elusive auto case when deemed necessary.

The following sections will highlight the official justifications for the tariffs, provide a timeline, and cover five of nine applicable cases. These were selected for showing interest in signing an agreement with the U.S. and successfully doing so. China was included by default for being designated the primary target of the tariffs.

Two cases (Argentina and Brazil) were excluded because official documents were mostly inaccessible. Two further cases that should have been covered but were not are Australia and Turkey. For Australia, official documents were unobtainable and the deal in its entirety was remarkably non-transparent. Regarding Turkey, it was not possible to provide any explanation or connection that did not rely on correlations. It is thus hoped that a follow-up study will cover either or both cases to explain these discrepancies. 


\section{Section 232 on Steel and Aluminium}

\section{General Order of Events}

Table one briefly visualises the order of events between April 19, 2017 and February 2020. Events thematically linked to the Section 232 investigations unfolding before April 2017 (such as AD, CVD, and other measures) are not included due to relevancy.

\begin{tabular}{|c|c|c|}
\hline Legal tool & Date & $\begin{array}{l}\text { Changes to Steel / Changes to Aluminium / Re- } \\
\text { marks }\end{array}$ \\
\hline Section 232 & April 19, 2017 & $\begin{array}{l}\text { (Steel) Investigation initiated by U.S. Secretary of } \\
\text { Commerce Wilbur Ross }\end{array}$ \\
\hline \multirow[t]{2}{*}{ Section 232} & April 26, 2017 & $\begin{array}{l}\text { (Aluminium) Investigation initiated by U.S. Sec- } \\
\text { retary of Commerce Wilbur Ross }\end{array}$ \\
\hline & December 2017 & $\begin{array}{l}\text { Several countries including the United Kingdom, } \\
\text { Japan, the EU (European Union), and the U.S. } \\
\text { confronted China at the WTO over excess capac- } \\
\text { ity }\end{array}$ \\
\hline $\begin{array}{l}\text { Proclamation } \\
9704\end{array}$ & \multirow{2}{*}{ March 8, 2018} & $\begin{array}{l}\text { (Aluminium) ten per cent ad valorem tariffs on al- } \\
\text { uminium imports, except from Canada and Mex- } \\
\text { ico }\end{array}$ \\
\hline $\begin{array}{l}\text { Proclamation } \\
9705\end{array}$ & & $\begin{array}{l}\text { (Steel) twenty-five per cent ad valorem tariffs on } \\
\text { steel imports, except from Canada and Mexico }\end{array}$ \\
\hline $\begin{array}{l}\text { Proclamation } \\
9710\end{array}$ & March 22, 2018 & $\begin{array}{l}\text { (Aluminium) Temporary exemptions for Aus- } \\
\text { tralia, Argentina, South Korea, Brazil, and the EU } \\
\text { (from May 1, 2018) }\end{array}$ \\
\hline $\begin{array}{l}\text { Proclamation } \\
9711\end{array}$ & March 28, 2018 & $\begin{array}{l}\text { (Steel) Temporary exemptions for Australia, Ar- } \\
\text { gentina, South Korea, Brazil, and the EU (from } \\
\text { May 1, 2018) }\end{array}$ \\
\hline $\begin{array}{l}\text { Proclamation } \\
973\end{array}$ & \multirow[t]{2}{*}{ April 30, 2018} & $\begin{array}{l}\text { (Aluminium) Exemptions for Argentina, Aus- } \\
\text { tralia, and Brazil prolonged indefinitely; tempo- } \\
\text { rary exemptions extended for Canada, Mexico, } \\
\text { and the EU (until June 1, 2018) } \\
\text { (Remarks) Agreement in principle with Argen- } \\
\text { tina, Australia, and Brazil. Threats to reimpose } \\
\text { tariffs for unsatisfactory implementation }\end{array}$ \\
\hline $\begin{array}{l}\text { Proclamation } \\
9740\end{array}$ & & $\begin{array}{l}\text { (Steel) Permanent exemption for South Korea; ex- } \\
\text { emptions for Argentina, Australia, and Brazil pro- } \\
\text { longed indefinitely; temporary exemptions ex- } \\
\text { tended for Canada, Mexico, and the EU (until } \\
\text { June 1, 2018) }\end{array}$ \\
\hline
\end{tabular}




\begin{tabular}{|c|c|c|}
\hline & & $\begin{array}{l}\text { (Remarks) Successful negotiations (KORUS); } \\
\text { Agreement in principle with Argentina, Australia, } \\
\text { and Brazil. Threats to re-impose tariffs for unsat- } \\
\text { isfactory implementation }\end{array}$ \\
\hline $\begin{array}{l}\text { Proclamation } \\
9758\end{array}$ & \multirow{2}{*}{ May 31, 2018} & $\begin{array}{l}\text { (Aluminium) Permanent tariff exemption for Aus- } \\
\text { tralia and Argentina; quotas for Argentina } \\
\text { (Remarks) agreed on measures to reduce excess } \\
\text { aluminium and prevent transhipment }\end{array}$ \\
\hline $\begin{array}{l}\text { Proclamation } \\
9759\end{array}$ & & $\begin{array}{l}\text { (Steel) Permanent tariff exemption for Argentina } \\
\text { and Brazil; replaced by individual quotas } \\
\text { (Remarks) agreed on measures to reduce excess } \\
\text { steel and prevent transhipment }\end{array}$ \\
\hline \multirow[t]{2}{*}{ Section 232} & May 23, 2018 & $\begin{array}{l}\text { (Autos) Investigation initiated by U.S. Secretary } \\
\text { of Commerce Wilbur Ross }\end{array}$ \\
\hline & June 1, 2018 & $\begin{array}{l}\text { (Steel and Aluminium) Exemptions for the EU, } \\
\text { Canada, and Mexico expired }\end{array}$ \\
\hline $\begin{array}{l}\text { Proclamation } \\
9772\end{array}$ & August 10, 2018 & $\begin{array}{l}\text { (Steel) fifty per cent ad valorem tariff on imports } \\
\text { from Turkey (from August 13, 2018) }\end{array}$ \\
\hline $\begin{array}{l}\text { Proclamation } \\
9777\end{array}$ & August 18, 2018 & $\begin{array}{l}\text { (Remarks) Authorises U.S. Secretary of Com- } \\
\text { merce Wilbur Ross to adapt quotas and exemp- } \\
\text { tions }\end{array}$ \\
\hline $\begin{array}{l}\text { Proclamation } \\
9886\end{array}$ & May 16, 2019 & $\begin{array}{l}\text { (Steel) Tariffs on Turkey reverted to twenty-five } \\
\text { per cent ad valorem (from May 21, 2019) }\end{array}$ \\
\hline $\begin{array}{l}\text { Presidential } \\
\text { Memoran- } \\
\text { dum }\end{array}$ & May 17, 2019 & $\begin{array}{l}\text { (Remarks) USTR instructed to negotiate with Ja- } \\
\text { pan and the EU to address automotive threat }\end{array}$ \\
\hline $\begin{array}{l}\text { Proclamation } \\
9893\end{array}$ & \multirow{2}{*}{ May 19, 2019} & $\begin{array}{l}\text { (Aluminium) Permanent exemptions for Canada } \\
\text { and Mexico } \\
\text { (Remarks) "[....] successfully concluded discus- } \\
\text { sions with Canada and Mexico on satisfactory al- } \\
\text { ternative means to address the threatened impair- } \\
\text { ment of the national security [...]" (Trump 2019d: } \\
\text { 23983). }\end{array}$ \\
\hline $\begin{array}{l}\text { Proclamation } \\
9894\end{array}$ & & $\begin{array}{l}\text { (Steel) Permanent exemptions for Canada and } \\
\text { Mexico } \\
\text { (Remarks) "[...] successfully concluded discus- } \\
\text { sions with Canada and Mexico on satisfactory al- } \\
\text { ternative means to address the threatened impair- } \\
\text { ment of the national security [...]" (Trump 2019c: } \\
\text { 23987-23988) }\end{array}$ \\
\hline $\begin{array}{l}\text { Proclamation } \\
9980\end{array}$ & January 24,2020 & $\begin{array}{l}\text { (Steel) Expands list of products affected. Exemp- } \\
\text { tions remain (Argentina, Australia, Brazil, Can- } \\
\text { ada, Mexico, South Korea) }\end{array}$ \\
\hline
\end{tabular}


(Aluminium) Expands list of products affected. Exemptions remain (Argentina, Australia, Canada, Mexico)

Table 1: Section 232 timeline. Data source: Trump (2017, 2018a, 2018b, 2018c, 2018d, 2018e, 2018f, 2018g, 2018h, 2018i, 2018j, 2019b, 2019c, 2019d, 2020); DOC (2018a, 2018b, 2018c); USCBP (2019); Fefer and Jones (2019); Fefer et al. (2019); Bown and Kolb (2020).

\section{Case Specifics: Aluminium}

The global share of U.S. primary aluminium production decreased from thirty per cent in 1981 to 1.5 per cent in 2016 (DOC 2018a: 24). Many smelters either disappeared or were left idling with only two in five producing at full capacity in 2017-despite growing demand (DOC 2018a: 2-3, 239).

From 2000 to 2017, China increased its global output from eleven to more than fifty per cent (DOC 2018a: 235). It is argued that China encouraged this increase to fuel domestic growth but failed to limit output once growth slowed down, leading to global overcapacity (Kahrs 2018: 184-185). In some product categories such as Harmonised Tariff Schedule (HTS) 7606 (plate, sheet, and strip) and 7607 (foil), China replaced the U.S. as the largest producer globally (DOC 2018a: 53).

The U.S.' decline in primary aluminium production began decades before China became a relevant producer (Vazquez 2018: 219) and the U.S. still enjoys a (shrinking) trade surplus in aluminium (Vazquez 2018: 218). Furthermore, China does not export primary aluminium, the material blamed for idling facilities (Fefer et al. 2019: $15)$.

In fact, China is only the largest supplier in some downstream categories (HTS 7606; 7607; 7609; 7616) (see DOC 2018a: 69); for almost everything else, Canada is the greatest source with a share of forty per cent of all aluminium imports, compared to China's ten per cent (DOC 2018a: 52, 65; Vazquez 2018: 220). Since most U.S. manufacturers have facilities in Canada, demands for tariffs exemptions were unanimous.

The Section 232 report targeted a utilisation rate of eighty per cent of domestic capacity and made two suggestions to achieve that goal (accounting for possible exemptions) (DOC 2018a: 107): option one either requires a worldwide quota of 86.7 per cent or a tariff rate of 7.7 per cent on several aluminium product categories (DOC 2018a: 108); and option two proposes an import cap at one-hundred per cent of 2017 volumes and a tariff rate of 23.6 per cent on aluminium product imports from unreliable sources with substantial overcapacity or tendencies to tranship, namely China, Hong Kong, Russia, Venezuela, and Vietnam (DOC 2018a: 109). The report suggested issuing exemptions in exchange, for example, for cooperation in addressing global overcapacity, which would than require an adjustment of tariffs or quotas (DOC 2018a: 109). 
The administration chose global tariffs of ten per cent -2.3 per cent higher than recommended with no adjustments made despite several exemptions. Currently, Argentina, Australia, Canada, and Mexico are exempt, while Argentina is subject to a quota (USCBP 2019).

\section{Case Specifics: Steel}

Steel mills decreased from 144 (105 individual companies) in 2000 to ninety-three (thirty-eight companies) in 2017 (DOC 2018b: 43). Currently "[...] only twenty-six percent of domestic steel is produced from raw materials [...]" (DOC 2018b: 43), down from fifty-three per cent in 2000. This is attributed to the replacement (or idling) of basic oxygen furnaces (BOF) with electric arc furnaces (EAF). The latter use scrap metal for steel production (DOC 2018b: 43). Steel employment decreased by thirtyfive per cent since 2001 (DOC 2018b: 16).

The U.S. was the largest steel importer in 2017, with imports accounting for thirty per cent of domestic demand (DOC 2018b: 3). The Department of Commerce (DOC) emphasises the significance domestic steel production has to U.S. security by referring to past administrations, ${ }^{7}$ which usually responded with a wide range of measures (tariffs, quotas, VRA, ${ }^{8}$ but mostly AD and CVD) when imports reached a share of twenty per cent of domestic consumption (DOC 2018b: 2-3, 6, 24, 249-250).

$\mathrm{AD}$ and CVD protection is seen as problematic because its per-case application makes duties easy to circumvent, and the requirement to file complaints makes the complainant an easy target for retaliation (DOC 2018b: 29). Furthermore, AD and CVD "[...] orders can make the United States a relatively high-priced island [...]" (Pearson 2016: 6), which hurts competitiveness downstream.

Although China is named the greatest threat, they were only the ninth biggest steel supplier in 2016, notably because AD and CVD orders have significantly reduced their footprint in the U.S. market since 2006 (to the benefit of others) ${ }^{9}$ (Leibowitz 2017: 3). The Department of Commerce (DOC) contended that Chinese exports did not decrease but were obscured through transhipments (predominantly via Vietnam and Thailand), a systemic issue that cannot be addressed by AD and CVD actions (DOC 2018b: 261-262).

Like aluminium, military demand for steel is insignificant at 0.03 to three per cent of domestic production (DOC 2018b: 240). Many stress that a shortage is basically

\footnotetext{
${ }^{7}$ At least once under Presidents George W. Bush (b. 1946), George H. W. Bush (1924-2018) and Richard M. Nixon (1913-1994), twice under James E. Carter (b. 1924), and three times under William J. Clinton (b. 1946) and Ronald W. Reagan (1911-2004) (DOC 2018b: 6).

${ }^{8}$ Voluntarily restraint agreements (VRA) are negotiated restrictions of exports.

${ }^{9}$ As Chinese exports decreased, countless countries experienced an export surge, including Italy (eighty-six per cent), Spain (106 per cent), Turkey (238 per cent), Vietnam (506 per cent), Thailand (478 per cent), and the United Arab Emirates (358 per cent) (DOC 2018b: 28).
} 
unimaginable in the foreseeable future, partly because military use of steel has been mostly replaced by other materials such as aluminium and Kevlar (e.g., Platzer 2018: 2; Leibowitz 2017: 3).

The final report suggested two options. Option one required either a sixty-three per cent quota to cap steel imports at 2017 levels or a tariff rate of twenty-four per cent on all steel imports (DOC 2018b: 7-8). Alternatively, the report suggested a fiftythree per cent tariff rate and a capping of imports at 2017 levels for Brazil, South Korea, Russia, Turkey, India, Vietnam, China, Thailand, South Africa, Egypt, Malaysia, and Costa Rica (DOC 2018b: 8). Like above, the report recommended adjusting tariffs or quotas in case of exemptions (DOC 2018b: 9).

The administration chose to apply a worldwide tariff rate of twenty-five per centone per cent higher than recommended - and granted permanent exemptions to Argentina, Australia, Brazil, Canada, Mexico, and South Korea. Argentina, Brazil, and South Korea are instead subject to a quota (USCBP 2019).

\section{Defining "National Security"}

Given Section 232 was written with General Agreement on Tariffs and Trade (GATT) Article XXI (Security Exceptions) ${ }^{10}$ compliance in mind (Breuss and Christen 2019: 12), the investigation had to assume a Vietnam or World War Two-like scenario for the calculations to be compliant (DOC 2018b: 50-51).

Both investigations were based on the national security definition from a 2001 investigation into steel and iron ore (DOC 2018b: 1). It was " $[\ldots]$ determined that 'national defence' includes both defence of the United States directly and the 'ability to project military capabilities globally" (DOC 2018a: 12). The definition was further broadened to include the "[...] welfare of certain industries, beyond those necessary to satisfy national defence requirements, which are critical to minimum operations of the economy and government" (DOC 2018a: 1). These industries were defined as "critical industries" (DOC 2018a: 13).

The Department of Commerce (DOC) argued that the original list of critical industries and their projected demand for steel was outdated given the "[...] dramatic changes in the steel industry since 2001" (Trump 2018a: 11625). Thus, the twentyeight industries (see DOC 2001: 17) were replaced with sixteen (mostly) steel-using critical infrastructure sectors (DOC 2018b: 24) defined by Presidential Policy Directive 21 (PPD-21) from 2013 (see WH 2013).

In 1976, the Supreme Court ruled that "national security" had to be defined more narrowly than "national interest" (DOC 2001: 5). The 2018 report, however, stressed

\footnotetext{
${ }^{10}$ GATT Article XXI (Security Exceptions) allows for unilateral measures to protect national security during wartime (Breuss and Christen 2019: 12).
} 
that the law failed to define a threshold for when imported quantities would start impairing national security. It is argued that

[...] the statute does not require a finding that the quantities or circumstances are impairing the national security [thus arguably] this formulation leaves the matter to the Secretary's discretion, and makes evident that Congress expected an affirmative finding under Section 232 would occur before there is actual impairment of the national security (DOC 2018a: 13).

This reinterpretation essentially justifies pre-emptive measures - a necessary step given even the Department of Defence (DOD) did not believe that imports in the steel, aluminium, and automobile industries were likely to pose a threat given relatively low demand (DOD 2018: 1; see DOC 2001: 1). Nevertheless, an unusually broad criteria catalogue was adapted (see USC 2020a), including factors like excess industry capacity, availability of (human) resources, industry growth requirements, and the economic welfare of the nation as a whole (DOC 2018a: 15; USC 2020a).

\section{Justifying Action}

\section{Preserving Profits and Jobs}

As repeatedly highlighted (e.g., DOC 2018a: 24-25; Yu 2018: 14), military consumption pertains to only a fraction of total domestic production (under four per cent), which is why the investigation in 2001 was unable to find a threat to national security (DOC 2001: 1-2).

To justify action, the argument was thus flipped: it stresses that military procurement is insufficient to generate enough revenue in a free market environment for private businesses to operate profitably. Since they cannot rely on military contracts for income, other revenue streams are required to sustain production and prevent a decrease in capacity, which would be difficult to regain during a war (DOC 2018a: 57, 104-105; 2018b: 23, 49-50). The same argument is applied to staff; employees can lose their skills and jobs and retraining would require time and additional funds, both of which are in short supply in a war-like emergency (DOC 2018b: 34-35). Indeed, for aluminium, it was stressed that specific products require special skills, with capacity approaching concerning levels if imports continue to cause layoffs ${ }^{11}$ (DOC 2018a: 91).

Revenue is also important to sustain investment, research, and development to allow for more efficient production of increasingly better products (DOC 2018a: 9697; 2018b: 4). Since most U.S. producers are joint-stock companies, they depend on

\footnotetext{
${ }^{11}$ One could argue that jobs were rather negligible as mills became highly automated (Platzer 2018:

2). Protection of local tax revenue thus seems more likely (Gooch 2018: 120).
} 
substantial returns to keep share prices high in order to raise funds for future investments. ${ }^{12}$ This too is threatened by rising imports (Smith B. 2018: 103; Ferry 2018).

\section{Overcapacity and Price}

The weakened state of the industries in question is generally blamed on overcapacity ${ }^{13}$ from China, with a 737 million metric ton gap between supply and demand (DOC 2018b: 4-5). In fact, "excess capacity" was the main reason provided for initiating the investigation (Trump 2017: 1). Although China is at the centre of the blame (e.g., Gooch 2018: 120; DOC 2018a: 99), others like Korea, Taiwan, or Japan have also become targets (e.g., Smith B. 2018: 102). There has been significant doubt, however, as Section 232 might not be the right tool to address issues in the global market (Leibowitz 2017: 3, 5).

Additionally, the cause of most of the issues, namely price fluctuations in aluminium, might be unrelated to Chinese production. The DOC (2018a: 239) accused China of suppressing global prices via the London Metals Exchange (LME) ${ }^{14}$ but some blame market manipulation and speculation ${ }^{15}$ (e.g., McGreevy III 2018: 208-209; Vazquez 2018: 221). Severe market correction in 2016 is identified as the most likely cause for the issues currently faced by U.S. producers. The DOC acknowledged rebounding prices in 2017 but argued that Chinese capacities did not contract meaningfully enough to prevent a similar scenario from happening again (DOC 2018a: 102).

It was demonstrated that China hardly exports primary aluminium due to a fifteen per cent export tax (Vazquez 2018: 219). However, the DOC contends that China encourages exports of semi-finished goods for smelting in third markets. The resulting

\footnotetext{
12 This feature of the U.S. economy was already a major issue during the 1980 s when U.S. businesses were unable to compete against house-bank-based systems like those in Japan (Hanada 2019: 88).

13 The overcapacity issue has existed since at least the 1980s. The problem was 'solved' with various VRA (Irwin 2017: 620-621). Given these became illegal as a result of the WTO (Hanada 2019: 154), the Bush (Jr.) administration tried to address overcapacity through multilateral negotiations (Cooney 2002: CRS-1, 3-4) but abandoned efforts in 2005 (Fefer et al. 2019: 16). The situation became critical again in 2015 which lead to the founding of the Global Forum on steel excess on September 5, 2016 (BMWI 2017: 2).

${ }^{14}$ Aluminium is a global commodity traded on the LME. Global prices are thus driven by supply and demand and transferred to the U.S. market (DOC 2018a: 239). LME prices can be a reference for direct supply contracts but the LME itself is mostly a market of last resort (McGreevy III 2018: 207).

${ }^{15}$ The LME was allegedly targeted by financial speculation between 2010 and 2015. This caused aluminium to be hoarded, strain in global supply, and consequently an increase in the "Midwest Premium" of sixty-seven per cent (a physical market premium paid by U.S. users on top of the LME price). After U.S. pressure, the LME introduced reforms which led to severe market corrections and oversupply (McGreevy III 2018: 208-209; see Vazquez 2018: 221).
} 
primary aluminium is then transhipped to the U.S. market (DOC 2018a: 240). This supposedly justifies the need for broad protection beyond Chinese products.

\section{Allies and Transhipment}

Both reports focused on China and ignored that Canada is the largest supplier for steel and aluminium (Taylor 2018). Demands to exempt Canada were almost unanimous during the hearings, particularly since security cooperation with Canada has been "[...] codified in a number of bilateral defence agreements" (Taylor 2018) and was written into U.S. law. "U.S. Code $§ 2505$ : National technology and industrial base: periodic defence capability assessments," for example, states that Canada is part of the national defence industrial base (USC 2020b). Even though Canada is considered a reliable supplier, this dependency was considered risky because there would be no viable replacement in case of an emergency (DOC 2018a: 35). The DOC also stressed that Section 232 by statute does not foresee exceptions for allied nations no matter the case (DOC 2018a: 16).

While the report from 2001 granted exemptions to reliable allies, the 2018 report rejected that option (DOC 2018b: 16-17) because the administration believes that other countries are under increasing pressure to export to the U.S. to compensate for losses resulting from Chinese overcapacity (DOC 2018b: 16, 53-54). In addition, officials believe that including allies might "motivate" them to engage in decisive action against Chinese transhipment (Ferry 2018). It should be noted that the U.S. administration failed to provide any supporting data for their transhipment claims which undermines their argument (McMaken 2018).

\section{Unfair Competition}

Unfair practices like transhipment and industrial policy (mostly subsidies) was another focal point. The DOD, although rather critical towards both Section 232 reports, agreed "[...] that the systematic use of unfair trade practices [...] intentionally erode[s] our innovation and manufacturing industrial base [and thus] poses a risk to our national security" (DOD 2018: 1).

The "unfairness argument" has a long history (see Hanada 2019: 69-72). Here, it is established that China undermines the (rather blurry) concept of a "level playing field" (e.g., Rintoul 2018: 86) by not committing to the free market, lowering production costs through lax regulations and pollution (e.g., Chevalier 2018: 177), or circumventing WTO rules (e.g., Lapides 2018: 147). Chinese overcapacity was said to have resulted directly from subsidies, which allegedly aim to capture the entire value chain (for aluminium) (DOC 2018a: 239-240) to increases China's security and export unemployment to the U.S. (Rintoul 2018: 80-85). 


\section{Supply Chain}

U.S. production did not decline but shifted towards more profitable products (Vazquez 2018: 220). China's policies encourage the export of such products as well as technological upgrading. Their alleged abuse of technology transfer requirements is thus of increasing concern as it allows Chinese companies to compete in high-value-added sectors such as automotive and aerospace - both traditionally important to the U.S. (DOC 2018a: 95, 239-240). China managed to surpass the U.S. as the largest downstream producer in some product categories whereas the U.S. now runs a trade deficit (DOC 2018a: 4, 52, 85). This essentially equals a wealth transfer as China undertakes the more profitable refinement process instead of U.S. producers. Additionally, many fear the formation of a similar overcapacity issue for downstream markets (e.g., Lapides 2018: 147).

Imports of semi-finished aluminium products from China rose by 183 per cent between 2013 and 2015 (DOC 2018: 240). For steel, the share grew from seven in 2001 to twenty-five per cent in 2017, with some product categories reaching as high a share as seventy-four per cent (DOC 2018b: 29). Accordingly, the potential for China to seize control of the entire value chain has been of great concern as this might cause challenging dependencies (e.g., Robb 2018: 175). For this reason, measures had to affect the entire value chain, not just the upstream sectors (Newport 2018: 94).

\section{Foreign Reliance}

Complete reliance on imports for essential materials pertaining to national security was naturally identified as a threat (DOC 2018a: 24). With foreign suppliers, the DOD would also not be able to receive preferential treatment on orders (DOC 2018b: 46).

More specifically, the U.S. identifies reliance on primary aluminium, high-purity aluminium, and steel as a national security risk (DOC 2018a: 5). While no reason was given for why there might be an aluminium shortage, the DOC highlighted the dramatic reduction in BOF for steel (DOC 2018b: 43). Yet given how U.S. producers replaced BOF with EAF over the years (DOC 2018b: 44), the issue seems rather homegrown than import driven. ${ }^{16}$

The DOC's worries seem unnecessary as U.S. aluminium production vastly surpasses military demand. Even if domestic high-purity aluminium production disappeared, it is suggested that the military could supply itself using technologies such as

\footnotetext{
${ }^{16}$ Unlike foreign competitors, U.S. businesses have switched from BOF (thirty-one in 2016) to EAF (154 in 2016) over the last thirty years (DOC 2018b: 44). BOF have higher output but also higher energy consumption and require larger vertically integrated companies. EAF only require scrap metal and are largely operated by nonunion workforces (Platzer 2018: 1; Rhynew 2016). Given the need to cater to shareholders, EAF might be more in line with their expectations.
} 
fractional crystallisation (Vazquez 2018: 219). The DOD shares this sentiment (DOD 2018: 1).

The irony, as Timothy Taylor (2018) points out, is that both industries are heavily dependent on imported raw materials and the U.S. is highly reliant on bauxite and iron ore, both of which cannot be mined domestically due to high energy costs and low quality natural deposits (Lauterbach 2018: 204; DOC 2001: 11). Although the DOC (2018a: 21) acknowledged the issue, they did not include these resources in their investigation (DOC 2018a: 20) - despite yielding to the same foreign dependency issues (arguably even more so).

\section{Case Studies}

\section{China}

Although China was the main justification for new tariffs, no direct links could be identified. This was expected because China's footprint in the U.S. market for these products is relatively small as a result of $\mathrm{AD}$ and CVD protection. Naturally, this would make it harder for the U.S. to directly leverage market access for concessions. The reduction of overcapacity was one of the stated goals but (so far) the administration has not engaged China directly (in the context of Section 232).

\section{South Korea and KORUS}

South Korea was the third largest supplier for steel products in 2016 (DOC 2018b: 28). Therefore, it was expected that the U.S. would wield some power when it comes to market access for steel products.

This opportunity came with the renegotiation of the U.S.-South Korea Free Trade Agreement (KORUS), initiated in June 2017 (Lester, Manak, and Kim 2019). Negotiations were held under the Joint Committee (established with the original agreement), which allowed "[...] the need for Congress to vote to approve the new agreement" (Smith T. 2018) to be bypassed. Talks formally started in early January 2018, with a second round taking place one week after Mr. Trump announced tariffs under Section 201. The third round coincided with the announcement of tariffs under Section 232 (Lester, Manak, and Kim 2019). The latter became explicitly relevant as the Koreans sought a resolution within the KORUS talks (Fefer et al. 2019: 8). "[A]n agreement in principle on the general terms of amendments and modifications [...]" (USTR 2018a) was reached only a few days later on March 28, 2018 and the revised agreement was signed on September 24, 2018.

The most noticeable concession was a doubling of the quota for imported American cars exempt from meeting Korean standards (KMVSS) from 25,000 to 50,000 
cars per manufacturer (USTR 2018b: 6). This quota allows U.S. manufacturers to mostly ignore Korean regulations and save on costly modifications to their vehicles (USTR 2018c). Additionally, the agreement lessens Korea's demanding documentation and labelling process for imports (which is regarded a non-tariff barrier) (Lester, Manak, and Kim 2019; USTR 2018c) by ensuring that replacement parts for U.S. cars would not need to comply with KMVSS if they already complied with U.S. regulations (U.S. FMVSS). Under special (unspecified) conditions, imports would have to be approved regardless (USTR 2018b: 7). As is quite common for agreements of this kind (see Hanada 2019: 147), the U.S. clarified that (emission) testing done at home would have to be accepted by Korean authorities without the need for retesting upon market entry (USTR 2018b: 9).

To accommodate for the discrepancy between U.S. and Korean fuel economy and greenhouse gas emission regulations, the agreement obligates Korea to expand the "eco-credits" system used to compensate for higher than allowed emissions ${ }^{17}$ (Lester, Manak, and Kim 2019). Furthermore, "Korea will [ensure] that fuel economy targets in future regulations will be set taking U.S. regulations into account and will continue to include more lenient targets for small volume manufacturers" (USTR 2018c).

A long-standing issue from the original KORUS was addressed with the reaffirmation of policy changes to the Health Insurance Review and Assessment Service (HIRA). Despite agreeing to "[...] non-discriminatory and fair treatment for U.S. pharmaceutical exports" (USTR 2018c), Korea allegedly continued to devalued U.S. intellectual property and favoured Korean pharmaceutical companies with their reimbursements (Lester, Manak, and Kim 2019).

One of the lesser documented changes concerned AD and CVD actions. The U.S. reaffirmed its right to use them but committed to transparency when calculating margins (USTR 2018b: 1-2). According to Simon Lester, Inu Manak, and Kyounghwa Kim (2019), this "[is] a direct response to the frequent use of this type of import restriction by the United States."

In an (arguably) protectionist move, the U.S. extended the infamous "chicken tax" for Korea beyond its scheduled phase-out in 2021 by thirty years. This 'tax', originally implemented to punish Germany and others for discriminating against U.S. chicken imports in the 1960s (Erdmann-Keefer 1991: 121-122), puts twenty-five per cent import tariffs on light trucks (USTR 2018c).

Lastly, the U.S. agreed to an undefined "[...] range of measures, including measures to reduce excess steel production and excess steel capacity" (Trump 2018c: 20683). These allowed Korea to be exempt from the tariffs on steel, and replaced them by a quota of "[...] seventy percent of the average of its export levels from 2015

\footnotetext{
${ }^{17}$ The U.S. was granted an average of $17.9 \mathrm{~g} / \mathrm{km}$ (USTR 2018b: 10), which is roughly four $\mathrm{g} / \mathrm{km}$ higher than limits for other manufacturers (Transport Policy 2018).
} 
through 2017" (Tankersley 2018), effective May 1, 2018 (USTR 2018a). This particular measure was quickly identified as a voluntary export restraint (VER) (e.g., Smith T. 2018; Lester, Manak, and Kim 2019), a popular tool during the 1980s (see Hanada 2019: 142-143) but outlawed with the founding of the WTO (Hanada 2019: 154).

Reactions to the agreement were mixed. Some saw " $[. .$.$] an admirable in principle$ but flawed in practice victory" (Smith T. 2018) while others viewed it as "[...] basically the same agreement, with a few minor tweaks" (Fernández 2018). Yet some recognised a concerning precedent as economic concessions were traded for tariff exemptions (Jin and Lee 2018).

The Heritage Foundation criticised protectionist parts such as the extension of the "chicken tax" (Smith T. 2018), which is likely meant to secure the lucrative pick-up market for U.S. manufacturers (Fernández 2018). It was further noted that the agreement lacked any rules of origin clauses to prevent Chinese transhipment - the stated intent of Section 232 tariffs. The car quota may also turn out to be of little use as U.S. manufacturers already struggled to fill the previous quota (Smith T. 2018).

\section{Japan's Car Issue}

Japan is ranked the seventh and thirteenth largest steel and aluminium supplier respectively (DOC 2018a: 65), making it comparatively less dependent on the U.S. market for these exports. However, Japan has historically been highly vulnerable to restrictions on cars (Hanada 2019: 109). The threat of such tariffs and repeated assurances by Mr. Trump that an agreement could prevent them was reportedly enough to break Japan's resistance to new negotiations (Picone, Lincicome, and Saika 2019: 12).

An agreement in principle was quickly reached and it is expected to result in a substantial reduction in barriers (Picone, Lincicome, and Saika 2019: 1). It covers industrial tariffs and grants improved market access for U.S. agricultural goods (beef, pork, wheat, dairy, and others) valued at over seven billion dollars (a fifty per cent increase on current agriculture exports to Japan). The (also) enclosed "[...] United States-Japan Digital Trade Agreement [additionally] establishes high-standard rules in this area [...]" (WH 2019).

It was not yet confirmed if the agreement would grant exemption on cars, steel, and aluminium (Picone, Lincicome, and Saika 2019: 1-2). However, the agreement contains one section stating that " $[\ldots]$ both nations will refrain from taking measures against the spirit of these agreements and this Joint Statement [and] both nations will 
make efforts for an early solution to other tariff-related issues" (WH 2019). The statement can be interpreted as cementing the status quo-with neither an exemption nor new tariffs. ${ }^{18}$

\section{Canada, Mexico, and USMCA}

Canada is the largest supplier of steel and aluminium, with Mexico coming in fourth and tenth respectively (DOC 2018a: 65; 2018b: 28). Canada (and to a lesser extent Mexico) were presumably hit the hardest by these tariffs and are therefore most likely to seek an exemption.

The renegotiation of the North American Free Trade Agreement (NAFTA) - a process initiated by Mr. Trump that ran from spring 2017 to autumn 2018 - presented an opportunity (Goulder and Stewart 2020). Although United States Trade Representative (USTR) Robert E. Lighthizer stressed that Section 232 tariffs were unrelated (WH 2018a), "[...] the Administration implicitly and explicitly linked a successful outcome of the [NAFTA] renegotiation to maintaining the exemptions [Canada and Mexico enjoyed for the first few months]" (Fefer et al. 2019: 7). Shortly after exemptions expired, Canada and Mexico agreed to and signed the new USMCA in late 2018 (Goulder and Stewart 2020).

Meanwhile, successful midterm elections allowed the democrats to delay ratification and reopen the deal for further renegotiations (Nawaz and Wallach 2020). Alterations to environment and labour laws were made and the new agreement passed with overwhelming bipartisan support on January 16, 2020 (Nawaz and Wallach 2020) just a day after Mr. Trump signed the "phase one trade agreement" with China pertaining to tariffs under Section 301 (Rodriguez 2020).

USMCA raises the regional value content (RVC) requirement from 62.5 previously to seventy-five per cent (Goulder and Stewart 2020) and requires that vehicles contain at least seventy per cent regional steel and aluminium (Fefer et al. 2019: 8). A new "labour value content" rule requires thirty per cent of the components of a car to be made by workers earning at least sixteen dollars ${ }^{19}$ per hour (Goulder and Stewart 2020), which equals three times the average pay for auto workers in Mexico (Petras 2019). Compliance is ensured by reserving the right to send U.S. inspectors to Mexican factories (Rodriguez 2020).

Other added provisions limit regulation of online businesses regarding user privacy, liability for spreading fake information, and selling counterfeit products (Nawaz

\footnotetext{
18 The deal was arguably violated in early 2020 when the U.S. administration imposed follow-up tariffs on downstream products (Bown 2020).

${ }^{19}$ USMCA does not impose minimum wages, as it pertains to only thirty per cent of the car. The threshold is not a wage floor but an average and includes salaries of business managers and others (Goulder and Stewart 2020).
} 
and Wallach 2020). Law enforcement were authorised to stop suspicious goods in any signature country, coupled with harsher punishments for online piracy and satelliteor cable signal theft. The agreement also eased restrictions on Canada's dairy market to allow for additional exports worth U.S.\$560 million (Petras 2019). One provision containing extended IP protection for biologic drugs (pharmaceuticals) was removed by the democrats as it could have reinforced existing monopolies, which ultimately may have increased medicine prices in Mexico and Canada to U.S. levels (WH 2018a; Rodriguez 2020; Nawaz and Wallach 2020).

The Trump administration credited successful negotiations to Section 232 tariffs and the looming threat of more (cars) to come (Schneider-Petsinger 2019: 11). Yet USMCA did not resolve the issue; rather, a side agreement was struck on May 17, 2019, which supposedly allowed for "[...] aggressive monitoring and a mechanism to prevent surges in imports of steel and aluminium” (USTR 2019a). The agreement reserves the right to reinstate tariffs in case of unexpected import surges and limits retaliation to sectors affected by these tariffs (USTR 2019b: 2; 2019c: 1-2). A second side agreement pre-emptively granted exemptions for up to 2.6 million cars and light trucks which would be subject to potential tariffs under the third Section 232 investigation (Williams et al. 2019: 5; Petras 2019).

\section{Beef, Soy, and Liquid Gas_-Dealing with the European Union}

When adding up exports of all its member states, the European Union (EU) comes in fifth place in both categories (see DOC 2018a: 65; 2018b: 28). Although the dependence of individual states is comparatively low, the EU was one of the most active respondents.

After initial exemptions had expired in June 2018, both parties agreed on a new negotiation objective with the EU-U.S. Joint Statement of July 2018. Meant to address Section 232 tariffs as well as additional areas, it was defined by four principles with slight variations depending on the press release:

1. strengthen cooperation in the energy sector by easing the process for purchasing liquefied natural gas (LNG) (WH 2018b);

2. launch a new platform (EU 2018a) "[...] to reduce trade and bureaucratic obstacles between the United States and the EU to slash costs dramatically" (WH 2018b);

3. seek WTO reforms to address unfair trade practices (EU 2018a); and

4. set up an Executive Working Group to "[...] identify short-term measures to facilitate commercial exchanges and assess existing tariff measures" (EU 2018a).

The last part was missing from the American statement, signalling that the EU is obligated to deliver. The Section 232 tariffs were only mentioned in the last sentences in each statement (see EU 2018a; WH 2018b). 
The following developments directly referenced the joint statement and are thus considered strongly related. It is assumed that the EU is acting submissively in the hope of receiving an exemption without having to offer too much value in return.

Results quickly surfaced as imports of soy and soymeal increased by 283 and 3,337 per cent respectively in July 2018 (compared to July 2017) (EU 2018c). The U.S. was thus able to increase its market share from 0.3 previously to thirteen per cent (EU 2018c). Imports continued to rise by another ninety-six per cent until 2019, not only making the U.S. the biggest soy exporter to the $\mathrm{EU},{ }^{20}$ but also increasing the U.S.' share of all EU imports to sixty per cent (from thirty-three per cent in July 2017 to July 2018). Further increases are likely as soy has been cleared for use in biofuels (EC 2019: 7).

Imports of LNG increased significantly (by 593 per cent) between July 2018 and November 2019 (see figures 2 and 3). This made the EU the primary destination for U.S. LNG exports (EC 2019: 7), a somewhat astounding development for a resource that is reportedly not price competitive (Zawadzki 2019). Given the EU's heavy investments in LNG infrastructure, further increases seem likely (EU 2018b).

Negotiations "on the elimination of industrial tariffs" were authorised on April 15, 2019 (EC 2019). The U.S. meanwhile had raised the pressure by delaying their decision on automotive tariffs. These would affect the EU significantly (Breuss and Christen 2019:

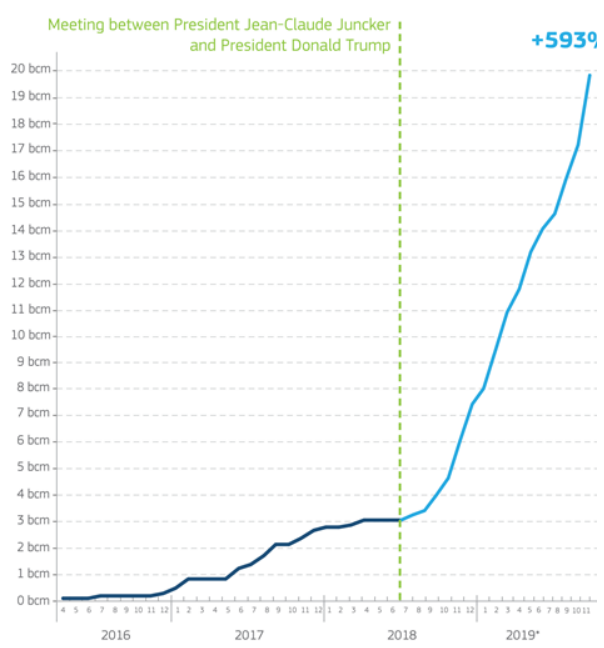

Figure 2: LNG imports from the U.S. Source: EU (2019c).

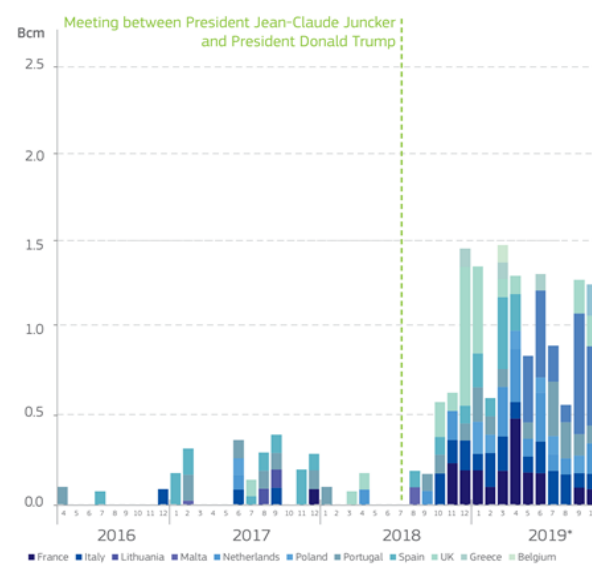

Figure 3: LNG imports from the U.S. by country. Source: EU (2019c). 17-18; see figure 4)

${ }^{20}$ Increased U.S. soy exports mostly displaced imports from Brazil, Ukraine, and Canada (EC 2019: 19). 
The first milestone was reached on July 11, 2019 and manifested in "[...] the full implementation of the Mutual Recognition Agreement on good manufacturing practices for human medicines" (EC 2019: 6). The agreement removed the requirement to retest medicine for import (EC 2019: 16), which is said to lower costs (EU 2019b). The U.S. still seeks an expansion of this rule to medical devices where they enjoy significant market share (forty-three per cent). The EU is apparently considering the proposal (EC 2019: 16).

Another agreement was signed on August 2, 2019 and

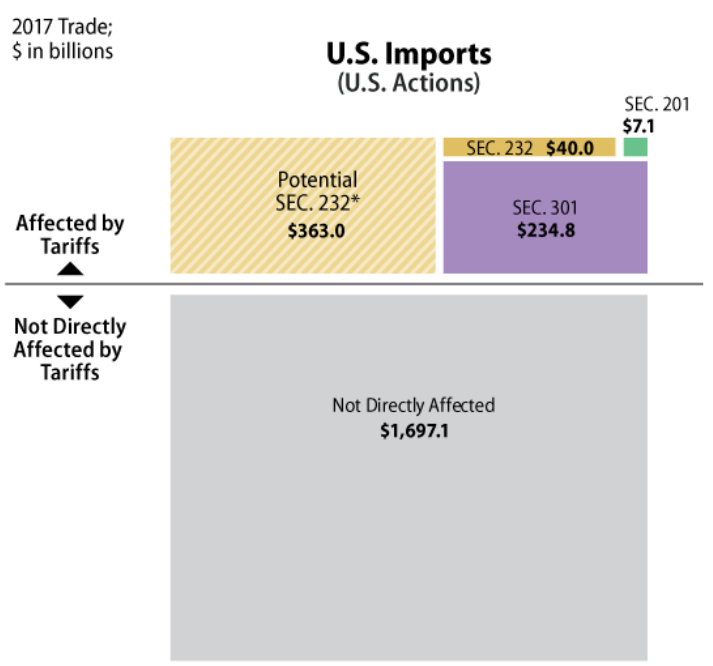

Figure 4: Tariffs overview by Section. Source: Williams et al. (2019: 17). Note: (*) Includes pending potential Section 232 tariffs on motor vehicles/parts and uranium imports. dealt with beef - a significant source of conflict for decades (Matthews 2015). It revised a duty-free import quota established by a Memorandum of Understanding (MoU) from 2009. ${ }^{21}$ Over the span of seven years, 35,000 (out of 45,000) tonnes of non-hormone treated beef will be reallocated exclusively to the U.S. (EU 2019a; EC 2019: 9). Export value is expected to increase by over 180 per cent (Trump 2019a). In exchange, the U.S. concluded a Section 301 investigation into beef initiated in December 2016 (USTR 2019e).

Additional sections focused on sectors typical for trade agreements with the U.S. - medical devices, pharmaceuticals, conformity assessments, and standards (EC 2019: 12; see Hanada 2019: 146). The agreement also featured some sections clearly dedicated to China, such as a declaration of intent to remain global rule makers in

\footnotetext{
${ }^{21}$ Beef is generally a sensitive topic since the EU banned the use of growth hormones and betaagonists in 1989. Given the U.S. had no non-hormone production certification programme, producers lost complete access to the EU market (Matthews 2015; Thelle et al. 2015: 60; Arita et.al 2014: 5). After retaliatory tariffs and a WTO case, the EU made the ban permanent in 2003. A second lost WTO case resulted in a MOU in 2009, which established beef quotas (Matthews 2015; EU 2009). The EU agreed to import 20,000 tonnes (eventual raised to 45,000 tonnes) of "high quality beef" (a category tailored to U.S. producers) duty free in exchange for the suspension of retaliatory tariffs (EU 2009: 4). The agreement required alterations in 2012 as additional countries had gained access over the years. The quota rose to 48,200 tons and allocation was changed to a first-come, first-served basis (EU 2014: 3; Matthews 2015). Due to increasing competition, the U.S.' share kept shrinking from seventy-five per cent initially (Matthews 2015; Igoe 2014).
} 
automated driving, AI, and other upcoming technologies (EC 2019: 11) — a direct attack on MIC 2025. Additionally, both countries stated their concerns over forced technology transfers and other forms of unfair trade (EC 2019: 8, 25).

The steel and aluminium issues were mostly neglected and neither addressed in the executive summaries nor the press releases (EU 2019b; EC 2019). Only the second agreement mandated joint pressure to "[...] eliminate subsidies and related excess capacities in the steel and semi-conductor sectors" (EC 2019: 24), the latter of which presumably also relates to MIC 2025. The EU also stressed that it "[...] expects the U.S. to roll back tariff measures on steel and aluminium" (EC 2019: 27). An elephant remains in the room, however, that the EU refers to at the end of its latest press release: ${ }^{22}$ looming car tariffs (EC 2019: 27). The U.S. administration did not grow tired of hinting at their elusive existence (Trump 2019a) and regularly stressed that only satisfactory negotiations could prevent them from taking shape (Hanke, Oliver, and Cassella 2018).

As the approximation in figure four suggests, these tariffs and their potential economic consequences could be severe (Fefer et al. 2019: 25). Unlike the steel and aluminium tariffs, they are believed to be "[...] a credible threat to the EU and Germany [...]" (Hübler and Herdecke 2019: 5). As such, they encapsulate the significant bargaining power that the U.S. will likely exploit in order to check a few boxes on their extensive trade wish list (see USTR 2019d). U.S. officials only recently tried to receive further concessions on poultry and hormone-treated beef by threatening car tariffs (Der Standard 2020a). United States Secretary of the Treasury Steven Mnuchin shortly after abused the potential threat to discourage any attempts by EU countries to tax U.S. internet companies (Der Standard 2020b).

\section{Discussion}

Overall, two elements became apparent quickly: first, although China served as the justification, the country became practically irrelevant once tariffs were in place; and second, despite tariffs having been enacted to protect (allegedly) against foreign steel and aluminium imports for national security reasons, steel, aluminium, national security, nor any of the claims made by either report played much of a role in any of the negotiations that followed.

As others pointed out (Schneider-Petsinger 2019: 14), there was barely any engagement with China under Section 232; accordingly, the tariffs did little to address stated issues (such as overcapacity) directly—an expected result given relatively low

\footnotetext{
22 "The EU equally expects the U.S. to stand by its commitment to respect the spirit of the two Presidents' agreement and refrain from imposing any additional trade restrictions on imports from the EU, notably in the field of trade in cars and car parts" (EC 2019: 27).
} 
dependencies in targeted sectors. Even indirectly, however, there was hardly any push from the U.S. to address overcapacity or other issues within the negotiations. This suggests that either the subject was not important enough or these negotiations were neither the right place nor the right time to do so.

Generally, the U.S. did not seem particularly interested in talking about steel and aluminium as Japan and the EU experienced. It can be argued that the administration did not address the issues because it wants to protect these sectors and measures were thus non-negotiable. Yet the U.S. had no qualms engaging South Korea, Canada, or Mexico on the issue, all of which have significantly higher market share. Limited engagement may thus have resulted from knowing that their leverage against the EU and Japan was simply insufficient.

Furthermore, agreements like KORUS lacked rules of origin, which would have been essential to address transhipping claims. Additionally, (side) agreements on steel and aluminium were surprisingly hard to access, possibly because most of these deals resulted in (illegal) VER (Lee 2019: 498-499). The only 'legal' concession in this regard might be the regional content rule within USMCA.

What the U.S. truly " $[\ldots .$.$] determined [...] necessary and appropriate [...] to address$ the threat to the national security posed by imports [...] from these countries (Trump 2018g: 13355) can be split into two categories: concessions on market access and concessions on direct purchases. In both cases, outcomes had little to do with steel or aluminium and more with industries the U.S. considers vital. Thus, it was unsurprising that concessions were mainly sought in agriculture, automotives, pharmaceuticals, and financial and internet services.

Market access refers not just to a simple expansion of quotas (USMCA, EU) but primarily to more substantial outcomes. First, the U.S. sought mutual recognition of standards and regulations, which was found in all four cases. Examples include the mutual recognition of test data (KORUS, EU), circumvention of local standards (KORUS), restrictions on regulations of internet monopolies (USMCA, Japan), and strengthened IP protection (USMCA). Second, they created enforcement tools to ensure compliance which manifested in the form of inspection authority in foreign factories (USMCA) and IP protection through cross-border enforcement (USMCA).

Direct purchases were exclusive to the EU (LNG, soy). These can be considered a nice bonus but are certainly not preferred (see Hanada 2019: 129, 199). Purchase commitments are voluntary, which gives leverage to importers as they can threaten to stop importing. Due to their questionable legal situation, they also cannot be enforced through the WTO (Hanada 2019: 143). Only after the U.S. created better leverage by threatening car tariffs did the EU start making more valuable concessions on market access in contested goods (beef) and product standards (pharmaceuticals).

Some journalists have argued that "Mr. Trump [...] is taking credit for solving a crisis of his own making [because the] United States was pursuing much the same under Mr. Obama through [...] the Transatlantic Trade and Investment Partnership" 
(Swanson and Ewing 2018). This ignores one crucial difference: while countries chose between a mutual agreement or the status-quo in the past, they must now make concessions to regain the status-quo. The U.S. on the other hand does not need to offer anything the opponent did not already have.

It can be argued that all concessions were protectionist, but not in the traditional sense (except for the expansion of the chicken tax within KORUS). Rather, instead of protecting the home market, the U.S. is protecting the ability of domestic businesses to make profits abroad.

It seems noteworthy that the U.S. granted multiple exemptions on steel but hardly any on aluminium. This might suggest that the administration cares more about the latter than the former and could also imply some form of protectionism. It is believable that aluminium might be a critical sector given its importance to the aerospace industry. However, this protectionism might also be different in nature. It was pointed out that the U.S. mostly protected high value-added and intermediary goods and ignored cheaper inputs and assembled products, which do not appear any less important for national security (Bown 2019: 5). The U.S. justified the discrepancy by preventing transhipping of semi-finished goods from China. It is just as likely, however, that the U.S. is protecting one of the few sectors in which they still enjoy a trade surplus.

Reliance on foreign producers in the aerospace industry may require tech-transfer like specific material composition, which might be another serious concern, particularly regarding MIC 2025. If the U.S. is truly trying to curb China's technological progress, it would explain why the beef agreement (EU) featured a section about preventing excess capacity in semiconductors and why the investigation ignored basic inputs. Given similar recent measures against China (see Hanada 2019: 189), it is certainly plausible.

Another major discrepancy concerns the national security argument itself. According to the proclamation, "[a]ny country with which [the U.S. has] a security relationship is welcome to discuss [...] alternative ways to address the threatened impairment of the national security caused by imports from that country" (Trump 2018a: 11626). As Williams et al. (2019: 20) correctly alludes to, the phrasing is vague and the "[...] nature of these considerations remain undefined."

All countries receiving temporary exemptions supposedly already shared the U.S.' commitment to address global excess capacity (Trump 2018b: 13362). It is thus unclear how their commitment suddenly weakened, prompting the U.S. to 'reaffirm' it through negotiation. The reports suggested that the administration could trade exemptions for agreements but the end results (as shown above) seem unlikely to achieve the stated goal of "[...] increase[d] domestic capacity utilisation [...]" (Trump 2018f: 13356). It appears more probable that the administration focused on the latter part of that sentence and aimed to achieve "[...] other satisfactory alternative means [...]" (Trump 2018f: 13356). 
To recall, the reports imagined a World War Two-like scenario to justify measures, because even though the U.S. has been at war non-stop since 2001, production fell idle (DOC 2001: 18). If the threat is truly as major as the report claimed, negotiation outcomes on agriculture, digital services, or pharmaceuticals would certainly not be satisfactory. Speaking from a neorealist point of view, it seems odd that the U.S. did not trust their decades-old security relationship with Canada, which is written into U.S. law. Yet a simple side agreement was a satisfactory proof of trust? Furthermore, if national security truly was at stake (as claimed), concessions are highly unlikely (Gilpin 1987: 31-32). As Taylor (2018) argued, "[i]f the national security concerns are legitimate, [it] seems like a remarkably sloppy and unserious way to address them." In short, the fact that national security became a tradeable commodity undermines the entire argument.

Within negotiations, a correlation between dependency on the U.S. market and willingness to negotiate could be observed. The utilisation of tariffs thereafter followed one of three strategies: pressure through existing tariffs, pressure through the threat of new tariffs, and the lingering threat of tariff-reinstatement after negotiations.

South Korea, Canada, and Mexico were (to some degree) negotiating with the U.S. while tariffs came into effect. South Korea quickly reached an agreement shortly after Canada and Mexico were initially exempted because "[...] these discussions will be most productive if [affected] articles from these countries remain exempt from the tariff [...]" (Trump 2018j: 20678). Cynically, one might argue (as the EU did) that having a gun to one's head might indeed be rather productive, at least for one party. All exemptions expired eventually, and an agreement was struck and signed shortly after. However, tariffs were not immediately lifted, presumably because the U.S. had to renegotiate due to domestic elections and therefore still needed the leverage to ensure compliance. Thus, a solution was only found a year later (after negotiations had mostly concluded).

Tariffs on steel and aluminium appear insufficiently effective in regard to Japan and the EU. This could explain why the president initiated another Section 232 investigation, particularly "[...] with respect to imported automobiles and certain automobile parts from the European Union, Japan, and any other country the Trade Representative deems appropriate [...]" (Trump 2019f: 23434).

According to the White House, Japan did not even consider negotiations until the car threats started manifesting (WH 2018a). The EU on the other hand made slight concessions even before the auto threat (LNG, soy), but meaningful concessions (on pharmaceuticals and beef) would not happen until afterwards. The fact that the EU entered negotiations despite "having a gun to its head" was also seen as a small tactical victory for the U.S. (Schneider-Petsinger 2019: 18-19). 
Given the U.S. would neither grant an exemption nor publish the third Section 232 report, both Japan and the EU had to negotiate under a permanent state of uncertainty. ${ }^{23}$ As others have noted, "[ $\left.\mathrm{t}\right]$ he Trump administration's practice of going back and forth in its trade talks [...] to some extent reflects the fact that President Trump likes to keep the opposition around the negotiating table 'off balance'" (SchneiderPetsinger 2019: 11). In such a scenario, the nature of a concession drastically changes as EU Commission President Jean-Claude Juncker's (b. 1954) statement shows: "The major progress today is that our American friends agreed not to increase tariffs on cars and other products during the negotiation, which is a major concession by the Americans [...]" (Swanson and Ewing 2018). This impeccably illustrates the essence of this tactic as doing nothing becomes a concession.

Another strategy ties perfectly into the statement above as the U.S. has mastered the art of receiving concessions while retaining their leverage. Agreements are worded loosely (Japan), essentially allowing the U.S. to preserve its (car) threats for later. The same impacts upon the EU because the threat of car tariffs is only suspended for as long as talks are satisfactory. The U.S. will likely take full advantage of the unreleased report given its negotiation power.

With Canada and Mexico, the U.S. reserved the option of reinstating tariffs in case of unfavourable developments. Additionally, the agreement restricts Canada and Mexico's options for retaliation in the same sector (steel and aluminium), whichgiven the low import to export ratio of 4:1 (DOC 2018b: 3) - the administration is unlikely to care much about. Moreover, suspended tariffs (like those with South Korea) can be an effective enforcement tool.

Compliant countries are rewarded pre-emptively, possibly as a show of good will or as a signal to defectors. The USMCA and KORUS illustrate this as all signature countries received preventative exemptions from potential car tariffs (Trump 2019f: 23434).

An even more striking example can be found with the allegedly "cascading protection" from January 2020. Here, it was argued that Mr. Trump "[...] was imposing new tariffs to help an industry suffering because of his previous tariffs" (Bown 2020). In this case, protectionism could be a motive as the value of products in question is likely too small to become effective leverage. On the other hand, because all countries which previously signed an applicable agreement were exempted by default, those who (presumably) did not offer enough (like Japan and the EU) were hit.

\footnotetext{
${ }^{23}$ The question was not just if and when tariffs would come, but also how high they would be. "And so [Trump] announced that we're going to put a twenty percent tariff — could be twenty-five — on their cars coming in" (WH 2018a).
} 
The largest suppliers of the products in question were thus exempt right away, which meant the volume of imports affected by the new tariffs was reduced significantly (see figure 5), thus arguably offering little protection to domestic industries. These tariffs were announced and implemented on short notice without any chance for appeal (Bown 2020), which makes a protectionist motive even less likely given 'protected' parties had no voice. Therefore, it is argued that the move was mostly meant to send a message to defectors, showing that the administration would not hesitate to hastily implement drastic measures and protect only those who comply. This relates to game theory, where "[...] the players $[\ldots]$ restructure the game $[\ldots]$ to

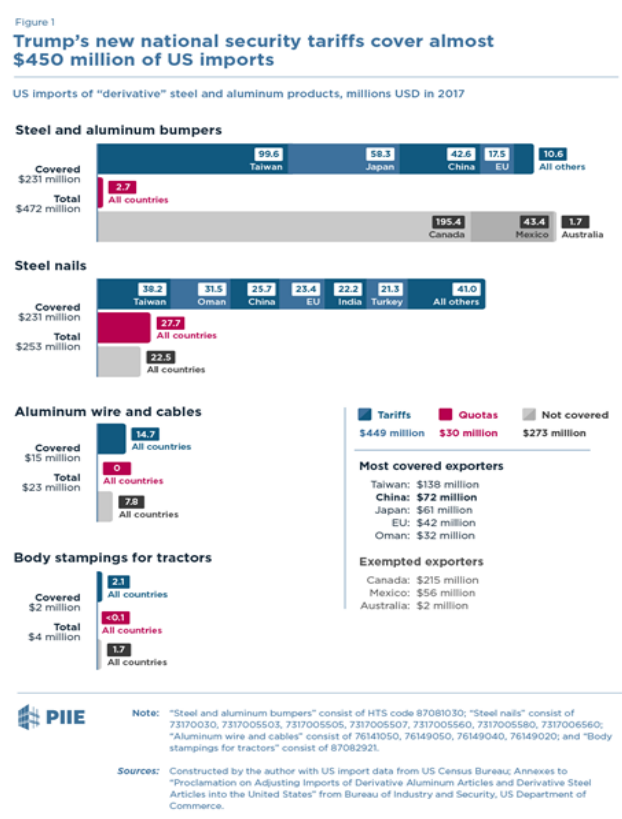

Figure 5: January 2020 tariffs. Source: Bown (2020). alter one another's perceptions of the costs of no-agreement and the benefits of proposed agreements" (Putnam 1988: 454).

Given all of the above, it may seem like this study suggests that the U.S. was planning this in advance, which is not the case. Rather, as I shall go on to discuss, this study believes that the tariffs were also enacted for vote-pandering purposes and additionally exploited wherever possible.

The U.S. could not have known what it would be able to bargain for, but officials knew that they would be able to receive something. This claim is based on the fact that the administration outright applied higher tariffs than recommended by either report but failed to explain their decision and did not adjust tariffs after granting significant exemptions (e.g., Trump 2018f: 11620). This implies that either the administration was increasing their leverage or they pre-emptively adjusted the rate because they expected to grant exemptions eventually.

It also puts another dent in the protection argument because exemptions were granted to the largest suppliers without readjustments. This is significant because if the administration wanted to exempt these countries specifically, they could have done so from the start by adapting the alternative option suggested by either report. These would have applied even higher tariffs but only to "problem countries." However, choosing that option would have drastically narrowed the administration's potential agreement partners, and may have principally included countries that the U.S. 
does not seek any concessions from. This too puts doubt on the transhipment justification as suggested alternatives specifically targeted China and countries accused of transhipping Chinese goods. Furthermore, exemptions for Canada and Mexico have been demanded unanimously right from the beginning but were only granted after both countries yielded to U.S. demands. This also sheds doubt on the protectionism argument as 'protected parties' predominantly owned facilities in Canada and were thus affected more significantly than China.

At this point, it has been clearly established that the current administration has been using Section 232 akin to Section 301 - in one case literally concluding a Section 301 case under Section 232 (EU beef). This naturally raises the question of why this approach was chosen, especially because these cases concerned a mixture of subsidies and merchandise, which is where Section 301 usually shines (Elliott and Richardson 1997: 216). U.S. officials might argue that Section 301 is too targeted and not broad enough to respond to transhipping. Here, however, it is explicitly argued that because the issue might involve subsidies, the U.S. could not use Section 301 as the WTO requires all such cases to be redirected to formal dispute settlement proceedings (Williams et al. 2019: 36). In such a setting, it is rather unlikely that the U.S. would have been able to receive even half of the concessions presented here. There certainly is historic precedent given U.S. officials similarly bypassed the GATT and WTO in favour of unilateral enforcement (e.g., Hanada 2019: 47-48).

Congress was another issue for the administration as it enjoys overwhelming authority on trade policy (Irwin 2017: 2). Just like the government used the Joint Committee to circumvent Congress in order to renegotiate KORUS (Smith T. 2018), they opted for Section 232 because it "[...] does not require congressional approval of any presidential actions that fall within its scope" (Fefer et al. 2019: 1). The same is not true for Section 301, where congress is more involved (Hanada 2019: 106).

Lastly, because Section 232 enjoys special privilege under the WTO, its legal standing is much stronger. Given the WTO lacks authority in questions of national security, the U.S. is almost unrestricted in its ability to exploit its market power for setting trade policy (see Broda, Limão, and Weinstein 2006: 1). Consequently, the national security argument must be seen as nothing more than a convenient fig leaf to loosen the shackles of international trade law (see Taylor 2018).

The remaining question is why China got lumped in despite lacking factual overlap. As initially mentioned, there is evidence for an "[...] electoral rationale for the pattern of tariffs increases" (Fajgelbaum et al. 2019: 3). This article also suggests that the tariffs had this second function which was obfuscated by "[...] a larger political strategy to throw every possible justification at the wall and see what sticks" (McMaken 2018). Since a trade war in the modern world "[...] is much more than the general public are ready to pay" (Sun and Wang 2018: 554), the U.S. might have resorted to a "Gamma paradigm" as proposed by Robert Axelrod whereby “[...] the U.S. president 
pursues policies vis-a-vis [an adversary] with an eye towards maximising his popularity at home" (Putnam 1988: 434). "Getting tough" with their emerging greatest rival would certainly qualify (Hanada 2019: 64-66). In short, the U.S. might be pursuing a different kind of two-level game where the administration pretends to care for voters in order to receive their backing to pursue their own concealed interests. A follow-up study might be able to explore this possibility in more detail.

\section{Conclusion}

This study began with a bold claim from which it derived three expectations, all of which can be considered met. Section 232 of the Trade Expansion Act of 1962 was shown to have been used in a similar fashion to Section 301 of the Trade Act of 1974 - as in artificially erecting barriers to serve as bargaining counters. A correlation between market share and susceptibility was observable, particularly threats against Japan vis-à-vis car exports. Results also strongly suggest that China was not the primary target of these measures. Furthermore, as the contrast between the reports and the five case studies has shown, stated rationales behind tariffs and their factual utilisation differed in multiple aspects, which certainly can explain why the "Trump tariffs" are generally hard to grasp.

The idea that tariffs under Section 232 were used for protecting domestic industries (e.g., Williams et al. 2019: 17) was cast in serious doubt alongwith the assumption that tariffs were intended to increase employment (e.g., Li, He, and Lin 2018: 1575). There is strong evidence that unlike traditional protectionism, these tariffs are not shielding the home market or jobs in low wage industries; rather, they are protecting (or rather creating) export opportunities and (mostly) jobs in high-paying industries. In a sense, they are protectionist but simultaneously are not. Arguably, a protectionist law like Section 232 was used because it allowed officials to bypass Congress and its legal standing vis-à-vis the WTO is stronger.

Justifications became practically irrelevant when measures were taken. China was not engaged in any claims made by the U.S. and nor were others; officials showed no interest in addressing steel and aluminium issues. In cases where they were mentioned, resolutions were relegated to a single paragraph of a much larger agreement (e.g., South Korea), formed a separate agreement altogether (e.g., USMCA), or were not specifically addressed but rather vaguely implied (e.g., Japan). Concessions received in exchange for tariff relief did not appear to resolve any of the issues stated in either report, but rather created long-term market access for U.S. businesses by, for example, weakening protection standards (e.g., South Korea).

Tariffs were generally used in two ways: as leverage when negotiations were already underway (e.g., South Korea) or to force the opponent to the negotiation table (e.g., Japan). Yet even a successful conclusion would not solve the initial issue as 
tariffs and threats would only be suspended. Indeed, given the U.S. (thus far) only granted exemptions to nations that would have been exempt by default under the alternative method of protection recommended by the reports, it is suggested that the U.S. was never interested in defending national security but rather in signing favourable trade agreements. As national security became a tradeable commodity, U.S. officials essentially undermined their own argument.

In view of these results, this study supports the claims made during the court case introduced earlier by specifically showing that Section 232 is not currently used for import relief and thus might even be illegal (see Leibowitz 2017: 4). Therefore, this study can prove valuable for future legal challenges.

Furthermore, this study broke with the assumption that bystanders were caught in a crossfire between the U.S. and China (e.g., Schneider-Petsinger 2019: 13) by showing that China was not the target but merely a convenient scapegoat to justify erecting tariffs.

Additionally, this article was able to clearly demonstrate that the theoretical arguments made by either report could not have been further from factual utilisation of tariffs. Put simply, not a single claim made in favour of national security was even remotely addressed. Given this discrepancy, confusing messaging from the administration, and off-label use of trade laws, it is understandable why some might lose track. This study hopefully contributed to clearing-up the misperception.

Finally, negotiation results may have received lukewarm receptions as it was often lamented that they were minor upgrades at best and rebranding at worst (e.g., Tankersley 2018; Meunier 2019: 133). Here, it needs to be stressed that the U.S. was not only able to receive additional concessions by offering practically nothing in return but was also able to retain the leverage to do so. This not only supports Mr. Trump's claim that tariffs are powerful enough to generate results even without using them (e.g., WH 2018a) but also reconfirms the findings of the original study.

By analysing the context of the tariffs under Section 232 from the perspective of International Relations, this study demonstrates how trade law is used beyond its stated purpose and how tariffs can possess utility beyond immediate economic rationales. With common assumptions brought into question, these results strongly encourage a more nuanced discourse going forward.

\section{ABBREVIATIONS}

$\mathrm{AD}$

AI

BOF

CVD
Anti-Dumping

artificial intelligence

basic oxygen furnaces

Countervailing Duties 


$\begin{array}{ll}\text { DOC } & \text { U.S. Department of Commerce } \\ \text { DOD } & \text { U.S. Department of Defence } \\ \text { EAF } & \text { electric arc furnaces } \\ \text { EU } & \text { European Union } \\ \text { FMVSS } & \text { Federal Motor Vehicle Safety Standards } \\ \text { GATT } & \text { General Agreement on Tariffs and Trade } \\ \text { HIRA } & \text { Health Insurance Review and Assessment Service } \\ \text { HTS } & \text { Harmonised Tariff Schedule } \\ \text { KMVSS } & \text { Korea Motor Vehicle Safety Standards } \\ \text { KORUS } & \text { U.S.-South Korea Free Trade Agreement } \\ \text { LME } & \text { London Metals Exchange } \\ \text { LNG } & \text { liquefied natural gas } \\ \text { MIC } & \text { Made in China } \\ \text { MoU } & \text { Memorandum of Understanding } \\ \text { NAFTA } & \text { North American Free Trade Agreement } \\ \text { PPD-21 } & \text { Presidential Policy Directive 21 } \\ \text { RVC } & \text { regional value content } \\ \text { U.S. } & \text { United States } \\ \text { USMCA } & \text { United States-Mexico-Canada Agreement } \\ \text { USTR } & \text { United States Trade Representative } \\ \text { VER } & \text { voluntary export restraint } \\ \text { VRA } & \text { voluntarily restraint agreements } \\ \text { WTO } & \text { World Trade Organisation } \\ & \end{array}$

\section{REFERENCES}

Arita, Shawn, Jayson Beckman, Lindsay Kuberka, and Alex Melton. 2014. "Sanitary and Phytosanitary Measures and Tariff-Rate Quotas for U.S. Meat Exports to the European Union." Online: https://www.ers.usda.gov/webdocs/publications/37587/ldpm-245-01.pdf (accessed: February 20, 2020).

Bayard, Thomas O. and Kimberly Ann Elliott. 1994. Reciprocity and Retaliation in U.S. Trade Policy. Washington: Institute for International Economics.

Bhagwati, Jagdish N. 1991. "Aggressive Unilateralism: An Overview.” In Jagdish Bhagwati and Hugh T. Patrick, eds., Aggressive Unilateralism: America's 301 Trade Policy and the World Trading System. New York: Harvester Wheatsheaf, pp. 1-48.

BMWI. 2017. "Global Forum on Steel Excess Capacity Report.” Online: https://www.bmwi.de/ Redaktion/EN/Downloads/global-forum-on-steel-excess-capacity-report.pdf (accessed: February 20,2020).

Bown, Chad P. 2019. "United States Special Protection in Historical Perspective: 1974-2019." AEA, December 31, 2019; online: https:/www.aeaweb.org/conference/2020/preliminary/powerpoint/yihD3SiS (accessed: February 20, 2020).

Bown, Chad P. 2020. “Trump's Steel and Aluminum Tariffs Are Cascading Out of Control." PIIE, February 4, 2020; online: https:/www.piie.com/blogs/trade-and-investment-policy-watch/ trumps-steel-and-aluminum-tariffs-are-cascading-out-control (accessed: February 20, 2020). 
Bown, Chad P. and Melina Kolb. 2020. “Trump's Trade War Timeline. An Up-to-Date Guide.” Online: https://www.piie.com/sites/default/files/documents/trump-trade-war-timeline.pdf (accessed: February 20, 2020).

Bown, Chad P. and Eva Yiwen Zhang. 2019. "Measuring Trump's 2018 Trade Protection: Five Takeaways." PIIE, February 15, 2019; online: https://www.piie.com/blogs/trade-investmentpolicy-watch/measuring-trumps-2018-trade-protection-five-takeaways (accessed: February 20, 2020).

Breuss, Fritz and Elisabeth Christen. 2019. "Policy Brief: Trump's Trade Wars Implications for the EU and China." Online: https://fritz.breuss.wifo.ac.at/Breuss-Christen_Trumps_Trade_ Wars_Wifo-PB_13_08_2019.pdf (accessed: February 20, 2020).

Broda, Christian, Nuno Limão, and David Weinstein. 2006. "Optimal Tariffs: The Evidence." Online: https://www.nber.org/papers/w12033.pdf (accessed: February 20, 2020).

Chevalier, Paul-Henri. 2018. "Paul-Henri Chevalier President Jupiter Aluminum Corporation." Online: https://www.commerce.gov/sites/default/files/the_effect_of_imports_of_aluminum_on_the_national_security___with_redactions_-_20180117.pdf (accessed: February 20, 2020).

Conybeare, John A. C. 1987. Trade Wars: The Theory and Practice of International Commercial Rivalry. New York: Columbia University Press.

Cooney, Stephen. 2002. “CRS Report for Congress Steel: Key Issues for Congress.” Online: https://www.everycrsreport.com/files/20021007_RS21152_67ddf8e13f0c57826a1255aa 49463ba2841b52fe.pdf (accessed: February 20, 2020).

Der Standard. 2020a. "US-Minister wünscht sich Chlorhuhn im EU-Handelsdeal mit den USA." Der Standard, January 28, 2020; online: https://www.derstandard.at/story/2000113840079/usminister-wuenscht-sich-chlorhuhn-im-eu-handelsdeal-mit-der (accessed: February 20, 2020).

Der Standard. 2020b. "Trump: Ohne Handelsabkommen kommen 'sehr hohe' Strafzölle für EU." Der Standard, January 22, 2020; online: https://www.derstandard.at/story/2000113604908/ trump-ohne-handelsabkommen-kommen-sehr-hohe-strafzoelle-fuer-eu (accessed: February 20, 2020).

DOC. 2001. "The Effect of Imports of Iron Ore and Semi-finished Steel on the National Security: An Investigation Conducted under Section 232 of the Trade Expansion Act of 1962, as Amended." Online: https://www.bis.doc.gov/index.php/documents/section-232-investigations/ 81-iron-ore-and-semi-finished-steel-2001/file (accessed: February 20, 2020).

DOC. 2018a. "The Effect of Imports of Aluminum on the National Security: An Investigation Conducted under Section 232 of the Trade Expansion Act of 1962, as Amended." Online: https:/www.commerce.gov/sites/default/files/the_effect_of_imports_of_aluminum_on_the national_security_-_with_redactions___20180117.pdf (accessed: February 20, 2020).

DOC. 2018b. "The Effect of Imports of Steel on the National Security: An Investigation Conducted under Section 232 of the Trade Expansion Act of 1962, as Amended." Online: https://www.commerce.gov/sites/default/files/the_effect_of_imports_of_steel_on_the_national_security_-_with_redactions_-_20180111.pdf (accessed: February 20, 2020).

DOC. $2018 \mathrm{c}$ "U.S. Department of Commerce Initiates Section 232 Investigation into Auto Imports.” Department of Commerce, May 23, 2018. Online: https://www.commerce.gov/ news/press-releases/2018/05/us-department-commerce-initiates-section-232-investigationauto-imports (accessed: February 20, 2020).

DOD. 2018. "Memorandum for Secretary of Commerce." Online: https://www.commerce.gov/ sites/default/files/department_of_defense_memo_response_to_steel_and_aluminum_policy_recommendations.pdf (accessed: February 20, 2020). 
EC. 2019. "Progress Report on the Implementation of the EU-U.S. Joint Statement of 25 July 2018 Greater Together: Slashing Billions in Industrial Tariffs and Boosting Transatlantic Trade." Online: https://trade.ec.europa.eu/doclib/docs/2019/july/tradoc_158272.pdf (accessed: February 20,2020).

Elliott, Kimberly Ann and J. David Richardson. 1997. "Determinants and Effectiveness of 'Aggressively Unilateral' U.S. Trade Actions.” In Robert C. Feenstra, ed., The Effects of U.S. Trade Protection and Promotion Policies. University of Chicago Press, pp. 215-243.

Erdmann-Keefer, Vera. 1991. Agrarhandelskonflikte EG-USA. Analyse eines Dauerproblems. Kehl am Rein, Straßburg, and Arlington: N.P. Engel Verlag.

EU. 2009. "European Communities - Measures Concerning Meat and Meat Products (Hormones): Joint Communication from the European Communities and the United States." Online: https://trade.ec.europa.eu/doclib/docs/2009/november/tradoc_145411.pdf (accessed: February 20, 2020).

EU. 2014. "Revised Memorandum of Understanding with the United States of America Regarding the Importation of Beef from Animals Not Treated with Certain Growth-Promoting Hormones and Increased Duties Applied by the United States to Certain Products of the European Union." Official Journal of the European Union, January 30, 2014; online: https://eur-lex.europa.eu/legal-content/EN/TXT/PDF/?uri=CELEX:22014A0130(01) (accessed: February 20, 2020).

EU. 2018a. "Joint U.S.-EU Statement Following President Juncker's Visit to the White House." The European Union, July 25, 2018; online: https://ec.europa.eu/commission/presscorner/detail/en/STATEMENT_18_4687 (accessed: February 20, 2020).

EU. 2018b. "EU-U.S. Joint Statement of 25 July: European Union Imports of U.S. Liquefied Natural Gas (LNG) Are on the Rise.” The European Union, August 9, 2018. Online: https://ec.europa.eu/commission/presscorner/detail/en/IP_18_4920 (accessed: February 20, 2020).

EU. 2018c. "Follow-Up to the EU-U.S. Joint Statement of 25 July: Imports of U.S. Soybeans Increase by over 280\%." The European Union, August 1, 2018. Online: https://ec.europa.eu/commission/presscorner/detail/en/IP_18_4768 (accessed: February 20, 2020).

EU. 2019a. "The European Union and the United States Sign an Agreement on Imports of Hormone-Free Beef." The European Union, August 2, 2019; online: https://ec.europa.eu/commission/presscorner/detail/en/IP_19_5010 (accessed: February 20, 2020).

EU. 2019b. "EU-U.S. Trade Talks: One Year On, Commission Presents Progress Report." The European Union, July 5, 2019; online: https://ec.europa.eu/commission/presscorner/detail/en/ IP_19_4670 (accessed: February 20, 2020).

Fajgelbaum, P. D., P. K. Goldberg, P. J. Kennedy, and A. K. Khandelwal. 2019. "The Return to Protectionism.” Online: https://www.nber.org/papers/w25638.pdf (accessed: February 20, 2020).

Fefer, Rachel F. and Vivian C. Jones. 2019. "Section 232 of the Trade Expansion Act of 1962." Online: https://fas.org/sgp/crs/misc/IF10667.pdf (accessed: February 20, 2020).

Fefer, Rachel F., Brandon J. Murrill, Keigh E. Hammond, Michaela D. Platzer, Vivian C. Jones, and Brock R. Williams. 2019. "Section 232 Investigations: Overview and Issues for Congress.” Online: https://fas.org/sgp/crs/misc/R45249.pdf (accessed: February 20, 2020).

Fernández, Alexia. 2018. "Trump's New Trade Deal with South Korea, Explained.” Vox, September 25, 2018; online: https://www.vox.com/2018/9/24/17883506/trump-korea-trade-deal-korus (accessed: February 20, 2020).

Ferry, Jeff. 2018. "Why We Need Tariffs on Steel.” Prosperous America, February 28, 2018; online: https://www.prosperousamerica.org/why_we_need_tariffs_on_steel (accessed: February 20,2020$)$. 
Franken, Al. 2017. “Senator Franken Public Comment.” Online: https://www.bis.doc.gov/index.php/232-steel-public-comments/1866-senator-franken-public-comment/file (accessed: February 20, 2020).

Ghodsi, Mahdi, Julia Grübler, and Robert Stehrer. 2016. "Import Demand Elasticities Revisited." Online: https://wiiw.ac.at/import-demand-elasticities-revisited-dlp-4075.pdf (accessed: February 20, 2020).

Gilpin, Robert. 1987. The Political Economy of International Relations. Princeton, New Jersey: Princeton University Press.

Gooch, Jim. 2018. "Testimony of Representative Jim Gooch.” Online: https://www.commerce.gov/sites/default/files/the_effect_of_imports_of_aluminum_on_the_national_security__with_redactions_-_20180117.pdf (accessed: February 20, 2020).

Goulder, Robert and David Stewart. 2020. "NAFTA versus USMCA: Taxes, Tariffs, and Trade in North America." Forbes, January 22, 2020; online: https://www.forbes.com/sites/taxnotes/ 2020/01/22/nafta-versus-usmca-taxes-tariffs-and-trade-in-north-america/ (accessed: February 20, 2020).

Hanada, Eric. 2019. "The Economic Rivalry between Japan and the U.S. in the 1980s, and China and the U.S. since the 1990s." M.A. thesis, University of Vienna, Austria.

Hanke, Jakob, Christian Oliver, and Megan Cassella. 2018. "Juncker and Trump's Transatlantic Trade Truce Falters.” Politico, October 17, 2018; online: https:/www.politico.com/story/ 2018/10/17/trade-truce-europe-trump-911940 (accessed: February 20, 2020).

Hübler, Michael and Axel Herdecke. 2019. "The US Trade Dispute: Blunt Offense or Rational Strategy?” Online: https://doi.org/10.1080/13504851.2019.1644428 (accessed: February 20, 2020).

Igoe, Michael. 2014. “Argentina Gains Access to EU High Quality Beef Quota.” U.S. Meat Export Federation, August 8, 2014; online: https:/www.usmef.org/argentina-gains-access-to-eu-highquality-beef-quota/ (accessed: February 20, 2020).

Irwin, Douglas A. 2011. Peddling Protectionism. Smoot-Hawley and the Great Depression. Princeton and Oxford: Princeton University Press.

Irwin, Douglas A. 2017. Clashing over Commerce: A History of U.S. Trade Policy. Chicago and London: The University of Chicago Press.

Jin, Hyunjoo and Joyce Lee. 2018. "U.S., South Korea Revise Trade Deal, Korean Steel Faces Quota." Reuters, March 26, 2018; online: https://www.reuters.com/article/us-southkorea-tradeusa/u-s-south-korea-revise-trade-deal-korean-steel-faces-quota-idUSKBN1H206V (accessed: February 20, 2020).

Johnson, Harry G. 1952. "Optimum Welfare and Maximum Revenue Tariffs." The Review of Economic Studies, 19 (1), pp. 28-35.

Johnson, Harry G. 1954. "Optimum Tariffs and Retaliation.” The Review of Economic Studies, 21 (2), pp. 142-153.

Kahrs, Ben. 2018. "Testimony by Ben Kahrs.” Online: https://www.commerce.gov/sites/default/ files/the_effect_of_imports_of_aluminum_on_the_national_security_-_with_redactions_20180117.pdf (accessed: February 20, 2020).

Lapides, John. 2018. “Testimony: Section 232 Investigation.” Online: https://www.commerce.gov/ sites/default/files/the_effect_of_imports_of_aluminum_on_the_national_security_-_with_redactions_-_20180117.pdf (accessed: February 20, 2020).

Lauterbach, Robert. 2018. "Oral Presentation on Section 232 National Security Investigation of Imports of Aluminum Presented." Online: https://www.commerce.gov/sites/default/files/ the_effect_of_imports_of_aluminum_on_the_national_security_-_with_redactions_20180117.pdf (accessed: February 20, 2020). 
Lee Yong-Shik. 2019. "Three Wrongs Do Not Make a Right: The Conundrum of the US Steel and Aluminum Tariffs." World Trade Review, 18 (3), pp. 481-501.

Leibowitz, Lewis E. 2017. "Law Office of Lewis Leibowitz Public Comment.” Online: https://www.bis.doc.gov/index.php/232-steel-public-comments/1823-law-office-of-lewisleibowitz-public-comment/file (accessed: February 20, 2020).

Lester, Simon, Inu Manak, and Kyounghwa Kim. 2019. "Trump's First Trade Deal: The Slightly Revised Korea-U.S. Free Trade Agreement." Cato Free Trade Bulletin, June 13, 2019; online: https://www.cato.org/publications/free-trade-bulletin/trumps-first-trade-deal-slightly-revisedkorea-us-free-trade (accessed: February 20, 2020).

Li, Chunding, Chuantian He, and Chuangwei Lin. 2018. "Economic Impacts of the Possible China-US Trade War." Emerging Markets Finance and Trade, 54 (7), pp. 1557-1577.

Lu, Feng. 2018. "China-US Trade Disputes in 2018. An Overview." China \& World Economy, 26 (5), pp. 83-103.

Matthews, Alan. 2015. "TTIP and the Potential for US Beef Imports." Capreform, April 9, 2015; online: http://capreform.eu/ttip-and-the-potential-for-us-beef-imports/ (accessed: February 20, 2020).

Mavroidis, Petros C. 2016. The Regulation of International Trade. Volume 1: GATT. Cambridge: MIT Press.

Mayer, Wolfgang and Raymond Riezman. 1990. "Voter Preference for Trade Policy Instruments." In Raymond Riezman 2013, ed., International Trade Agreements and Political Economy. Singapore: World Scientific Publishing Co. Pte. Ltd., pp. 169-184.

McGreevy III, James A. 2018. "Testimony of President and Chief Executive Officer The Beer Institute." Online: https://www.commerce.gov/sites/default/files/the_effect_of_imports_of_aluminum_on_the_national_security_-_with_redactions_-_20180117.pdf (accessed: February 20, 2020).

McMaken, Ryan. 2018. "Not Even the Pentagon Thinks Tariffs Are Needed for National Defense." Mises Institute, March 10, 2018; online: https://mises.org/wire/not-even-pentagonthinks-tariffs-are-needed-national-defense (accessed: February 20, 2020).

Mearsheimer, John J. 1995. "The False Promise of International Institutions.” International Security, 19 (3), pp. 5-49.

Meunier, Sophie. 2019. "A Disorderly Retreat from Global Governance? US Trade and Investment Policies in the Trump Era.” In Jing Men, Simon Schunz, Duncan Freeman, eds., The Evolving Relationship between China, the EU and the USA: A New Global Order? London: Routledge, pp. 132-151.

Nawaz, Amna and Lori Wallach. 2020. "What Are the Differences between NAFTA and the USMCA?” PBS, January 16, 2020; online: https://www.pbs.org/newshour/show/what-are-thedifferences-between-nafta-and-the-usmca (accessed: February 20, 2020).

Newport, Roger K. 2018. "Testimony of Roger K. Newport Chief Executive Officer AK Steel Corporation." Online: https://www.commerce.gov/sites/default/files/the_effect_of_imports of_steel_on_the_national_security_-_with_redactions_-_20180111.pdf (accessed: February $20,2020)$.

Olson, Stephen. 2018. “Trump Tariffs, 101.” The Diplomat, May 30, 2018; online: https://thediplomat.com/2018/05/trump-tariffs-101/ (accessed: February 20, 2020).

Pearson, Daniel R. 2016. "Global Steel Overcapacity: Trade Remedy 'Cure' Is Worse Than the 'Disease.”' Online: https://www.bis.doc.gov/index.php/232-steel-public-comments/1923-daniel-r-pearson-cato-institute/file (accessed: February 20, 2020). 
Pearson, Daniel R. 2017. “Can Wilbur Ross Engineer a Turnaround at Commerce?” Online: https://www.bis.doc.gov/index.php/232-steel-public-comments/1923-daniel-r-pearson-catoinstitute/file (accessed: February 20, 2020).

Petras, George. 2019. "From NAFTA to USMCA: Key Changes on Trilateral Trade Pact ." USA Today, December 15, 2019; online: https:/eu.usatoday.com/story/news/2018/10/01/comparison-nafta-and-usmca-trade-agreements/1487163002/ (accessed: February 20, 2020).

Picone, Brian, Scott S. Lincicome, and Naoto Nelson Saika. 2019. "United States and Japan Reach 'Agreement in Principle', but Questions and Obstacles Remain." White \& Case, LLP, September 5, 2019; online: https://www.whitecase.com/sites/default/files/2019-09/wc-us-trade-reportunited-states-japan-reach-agreement-principle-questions-obstacles.pdf (accessed: February 20, 2020).

Platzer, Michaela D. 2018. "Trade Actions and U.S. Steel Manufacturing.” Online: https://crsreports.congress.gov/product/pdf/download/IF/IF10902/IF10902.pdf/ (accessed: February 20, 2020).

Putnam, Robert D. 1988. "Diplomacy and Domestic Politics: The Logic of Two-Level Games." International Organization, 42 (3), pp. 427-460.

Rashish, Peter S. 2018. "Making the Atlantic Great (Again)? Prospects for New U.S.-EU Trade Negotiations." Online: https://www.aicgs.org/site/wp-content/uploads/2018/09/IB-58-RashishMAGA.pdf (accessed: February 20, 2020).

Restani, Jane A. 2018. "Severstal Export GmbH, and Severstal Export Miami Corporation, Plaintiffs, v. United States of America, United States Customs and Border Protection, Acting Commissioner Kevin K. Mc Aleenan, Department of Commerce, Secretary Wilbur Ross, and President Donald J. Trump." Online: https://www.cit.uscourts.gov/sites/cit/files/18-37.pdf (accessed: February 20, 2020).

Rhynew. 2016. "BOF and EAF Steels. What Are the Differences?" Washington and Lee University, March 7, 2016; online: https://econ243.academic.wlu.edu/2016/03/07/bof-and-eaf-steelswhat-are-the-differences/ (accessed: February 20, 2020).

Riezman, Raymond. 1982. "Tariff Retaliation from a Strategic Viewpoint.” In Raymond Riezman 2013, ed., International Trade Agreements and Political Economy. Singapore: World Scientific Publishing Co. Pte. Ltd., pp. 21-32.

Rintoul, David J. 2018. “Testimony of David J. Rintoul.” Online: https://www.commerce.gov/ sites/default/files/the_effect_of_imports_of_steel_on_the_national_security_-_with_redactions_-_20180111.pdf (accessed: February 20, 2020).

Robb, Thomas. 2018. "Statement of Thomas Robb." Online: https://www.commerce.gov/sites/default/files/the_effect_of_imports_of_aluminum_on_the_national_security_-_with_redactions_20180117.pdf (accessed: February 20, 2020).

Rodriguez, Sabrina. 2020. "Senate Passes USMCA, but Much Work Remains.” Politico, January 16, 2020; online: https://www.politico.com/news/2020/01/16/senate-passes-usmca-in-majorwin-for-trump-099744 (accessed: February 20, 2020).

Schneider-Petsinger, Marianne. 2019. "US-EU Trade Relations in the Trump Era. Which Way Forward?” Online: https:/www.chathamhouse.org/sites/default/files/publications/research/ 2019-03-08US-EUTradeRelations2.pdf (accessed: February 20, 2020).

Sheng Liugang, Hongyan Zhao, and Jing Zhao. 2019. "Why Will Trump Lose the Trade War?" China Economic Journal, 12 (2), pp. 137-159.

Smith, Barbara. 2018. "Testimony of Barbara Smith.” Online: https://www.commerce.gov/ sites/default/files/the_effect_of_imports_of_steel_on_the_national_security_-_with_redactions_-_20180111.pdf (accessed: February 20, 2020). 
Smith, Tori. 2018. "Analyzing the Renegotiated U.S.-Korea Free Trade Agreement (KORUS)." The Heritage Foundation, April 13, 2018; online: https://www.heritage.org/trade/report/analyzing-the-renegotiated-us-korea-free-trade-agreement-korus (accessed: February 20, 2020).

Sposi, Michael and Kelvinder Virdi. 2018. "Steeling the U.S. Economy for the Impacts of Tariffs." Federal Reserve Bank of Dallas Economic Letter, 13 (5), pp. 1-4.

Sun, Tianhao and Yan Wang. 2018. "Trends of U.S.-China Trade Disputes and Beijing's Policy Options.” China Quarterly of International Strategic Studies, 4 (4), pp. 543-557.

Swanson, Ana and Jack Ewing. 2018. "Trump's Trade Truce with Europe Has a Familiar Feel: It Mirrors Obama's Path.” The New York Times, July 26, 2018; online: https://www.nytimes.com/2018/07/26/us/politics/trump-trade-european-union.html (accessed: February 20, 2020).

Tankersley, Jim. 2018. “Trump Signs Revised Korean Trade Deal.” The New York Times, September 24, 2018; online: https://www.nytimes.com/2018/09/24/us/politics/south-korea-trumptrade-deal.html (accessed: February 20, 2020).

Taylor, Timothy. 2018. "The National Security Argument for Steel and Aluminum Tariffs." Conversable Economist, March 7, 2018; online: http:/conversableeconomist.blogspot.com/2018/ 03/the-national-defense-argument-for.html (accessed: February 20, 2020).

The Economist. 2018. "Why Tariffs Are Bad Taxes." The Economist, July 31, 2018; online: https://www.economist.com/the-economist-explains/2018/07/31/why-tariffs-are-bad-taxes (accessed: February 20, 2020).

Thelle, Martin H., Tine Jeppesen, Jori Veng Pinje, Anders Kjøller-Hansen, Ronald B. Davies, and Joseph F. Francois. 2015. “TTIP Impact in Ireland.” Online: https://dbei.gov.ie/en/Publications/Publication-files/TTIP-Impact-in-Ireland-Study.pdf (accessed: February 20, 2020).

Transport Policy. 2018. "South Korea: Light-Duty: Fuel Economy and GHG." Online: https://www.transportpolicy.net/standard/south-korea-light-duty-fuel-economy-and-ghg/ (accessed: February 20, 2020).

Trump, Donald J. 2017. "Memorandum on Steel Imports and Threats to National Security." Online: https://www.govinfo.gov/content/pkg/DCPD-201700259/pdf/DCPD-201700259.pdf (accessed: February 20, 2020).

Trump, Donald J. 2018a. "Proclamation 9705 of March 8, 2018. Adjusting Imports of Steel into the United States." Federal Register, 83 (51), pp. 1625-11630. Online: https://www.govinfo.gov/content/pkg/FR-2018-03-15/pdf/2018-05478.pdf (accessed: February 20, 2020).

Trump, Donald J. 2018b. "Proclamation 9711 of March 28, 2018 Adjusting Imports of Steel into the United States." Federal Register, 83 (60), pp. 13361-13365. Online: https://www.govinfo.gov/content/pkg/FR-2018-03-28/pdf/2018-06425.pdf (accessed: February 20, 2020).

Trump, Donald J. 2018c. "Proclamation 9740 of April 30, 2018 Adjusting Imports of Steel into the United States." Federal Register, 83 (88), pp. 20683-20705. Online: https://www.govinfo.gov/content/pkg/FR-2018-05-07/pdf/2018-09841.pdf (accessed: February 20, 2020).

Trump, Donald J. 2018d. "Proclamation 9759 of May 31, 2018 Adjusting Imports of Steel into the United States." Federal Register, 83 (108), pp. 25857-25877. Online: https://www.govinfo.gov/content/pkg/FR-2018-06-05/pdf/2018-12140.pdf (accessed: February 20, 2020).

Trump, Donald J. 2018e. "Proclamation 9772 of August 10, 2018 Adjusting Imports of Steel into the United States." Federal Register, 158 (83), pp. 40429-40432. Online: 
https://www.govinfo.gov/content/pkg/FR-2018-08-15/pdf/2018-17703.pdf (accessed: February 20, 2020).

Trump, Donald J. 2018f. "Proclamation 9704 of March 8, 2018 Adjusting Imports of Aluminum into the United States." Federal Register, 83 (51), pp. 11619-11624. Online: https://www.govinfo.gov/content/pkg/FR-2018-03-15/pdf/2018-05477.pdf (accessed: February 20, 2020).

Trump, Donald J. 2018g. "Proclamation 9710 of March 22, 2018 Adjusting Imports of Aluminum into the United States." Federal Register, 83 (60), pp. 13355-13359. Online: https://www.govinfo.gov/content/pkg/FR-2018-03-28/pdf/2018-06420.pdf (accessed: February 20, 2020).

Trump, Donald J. 2018h. "Proclamation 9758 of May 31, 2018 Adjusting Imports of Aluminum into the United States." Federal Register, 83 (108), pp. 25849-25855. Online: https://www.govinfo.gov/content/pkg/FR-2018-06-05/pdf/2018-12137.pdf (accessed: February 20, 2020).

Trump, Donald J. 2018i. "Proclamation 9777 of August 29, 2018 Adjusting Imports of Steel into the United States." Federal Register, 83 (171), pp. 45025-45029. Online: https://www.govinfo.gov/content/pkg/FR-2018-09-04/pdf/2018-19284.pdf (accessed: February 20, 2020).

Trump, Donald J. 2018j. "Proclamation 9739 of April 30, 2018 Adjusting Imports of Aluminum into the United States." Federal Register, 83 (88), pp. 20677-20682. Online: https://www.govinfo.gov/content/pkg/FR-2018-05-07/pdf/2018-09840.pdf (accessed: February 20, 2020).

Trump, Donald J. 2019a. "Remarks by President Trump at Signing of a U.S.-EU Trade Agreement." The White House, August 2, 2019; online: https:/www.whitehouse.gov/briefings-statements/remarks-president-trump-signing-u-s-eu-trade-agreement/ (accessed: February 20, 2020).

Trump, Donald J. 2019b. "Proclamation 9886 of May 16, 2019 Adjusting Imports of Steel into the United States." Federal Register, 84 (98), pp. 23421-23423. Online: https://www.govinfo.gov/content/pkg/FR-2019-05-21/pdf/2019-10759.pdf (accessed: February 20, 2020).

Trump, Donald J. 2019c. "Proclamation 9894 of May 19, 2019 Adjusting Imports of Steel into the United States." Federal Register, 84 (100), pp. 23987-23989. Online: https://www.govinfo.gov/content/pkg/FR-2019-05-23/pdf/2019-11002.pdf (accessed: February 20, 2020).

Trump, Donald J. 2019d. "Proclamation 9893 of May 19, 2019 Adjusting Imports of Aluminum into the United States.” Federal Register, 84 (100), pp. 23983-23985. Online: https://www.govinfo.gov/content/pkg/FR-2019-05-23/pdf/2019-10999.pdf (accessed: February 20, 2020).

Trump, Donald J. 2020. "Proclamation 9980 of January 24, 2020 Adjusting Imports of Derivative Aluminum Articles and Derivative Steel Articles into the United States." Federal Register, 85 (19), pp. 5281-5293. Online: https://www.govinfo.gov/content/pkg/FR-2020-01-29/pdf/202001806.pdf (accessed: February 20, 2020).

USC. 2020a. "19 USC §1862. Safeguarding National Security.” Govinfo; online: https://www.govinfo.gov/content/pkg/USCODE-2018-title19/html/USCODE-2018-title19chap7-subchapII-partIV-sec1862.htm (accessed: February 20, 2020).

USC. 2020b. "10 USC $\S 2505$. National Technology and Industrial Base: Periodic Defense Capability Assessments." Cornell University; online: https://www.law.cornell.edu/uscode/text/ 10/2505 (accessed: February 20, 2020). 
USCBP. 2019. "U.S. Customs and Border Protection 'Section 232 Trade Remedies on Aluminum and Steel."' Online: https://www.cbp.gov/trade/programs-administration/trade-remedies/section-232-trade-remedies-aluminum-and-steel (accessed: February 20, 2020).

USTR. 2018a. "Joint Statement by the United States Trade Representative Robert E. Lighthizer and Republic of Korea Minister for Trade Hyun Chong Kim." United States Trade Representative, March 28, 2018; online: https://ustr.gov/about-us/policy-offices/press-office/press-releases/2018/march/joint-statement-united-states-trade (accessed: February 20, 2020).

USTR. 2018b. "Protocol between the Government of the United States of America and the Government of the Republic of Korea: Amending the Free Trade Agreement between the United States of America and the Republic of Korea." Online: https://ustr.gov/sites/default/files/ files/Press/Releases/KORUS\%20Texts\%20Outcomes.pdf (accessed: February 20, 2020).

USTR. 2018c. "New U.S. Trade Policy and National Security Outcomes with the Republic of Korea." United States Trade Representative; online: https:/ustr.gov/about-us/policy-offices/pressoffice/fact-sheets/2018/march/new-us-trade-policy-and-national (accessed: February 20, 2020).

USTR. 2019a. "United States Announces Deal with Canada and Mexico to Lift Retaliatory Tariffs." United States Trade Representative, May 17, 2019; online: https://ustr.gov/about-us/policy-offices/press-office/press-releases/2019/may/united-states-announces-deal-canada-and (accessed: February 20, 2020).

USTR. 2019b. "Joint Statement by the United States and Mexico on Section 232 Duties on Steel and Aluminum.” Online: https://ustr.gov/sites/default/files/Joint_Statement_by_the_United States_and_Mexico.pdf (accessed: February 20, 2020).

USTR. 2019c. "Joint Statement by the United States and Canada on Section 232 Duties on Steel and Aluminum." Online: https://ustr.gov/sites/default/files/Joint_Statement_by_the_United_ States_and_Canada.pdf (accessed: February 20, 2020).

USTR. 2019d. "United States-European Union Negotiations. Summary of Specific Negotiating Objectives.” Online: https:/ustr.gov/sites/default/files/01.11.2019_Summary_of_U.S.-EU_ Negotiating_Objectives.pdf (accessed: February 20, 2020).

USTR. 2019e. "United States and European Union Sign Breakthrough Agreement on U.S. Beef Access to EU." United States Trade Representative, August 2, 2019; online: https://ustr.gov/ about-us/policy-offices/press-office/press-releases/2019/august/united-states-and-europeanunion (accessed: February 20, 2020).

Vazquez, Jorge. 2018. "Written Testimony by Jorge Vazquez.” Online: https://www.commerce.gov/sites/default/files/the_effect_of_imports_of_aluminum_on_the_national_security__with_redactions_-_20180117.pdf (accessed: February 20, 2020).

Waltz, Kenneth N. 2000. "Structural Realism after the Cold War." International Security, 25 (1), pp. 5-41.

Williams, Brock R., Cathleen D. Cimino-Isaacs, Rachel F. Fefer, Keigh E. Hammond, Vivian C. Jones, Wayne M. Morrison, and Andres B. Schwarzenberg. 2019. "Trump Administration Tariff Actions (Sections 201, 232, and 301): Frequently Asked Questions." Online: https://crsreports.congress.gov/product/pdf/download/R/R45529/R45529.pdf/ (accessed: February 20, 2020).

WH. 2013. "Presidential Policy Directive - Critical Infrastructure Security and Resilience." The White House Office of the Press Secretary, February 12, 2013; online: https://obamawhitehouse.archives.gov/the-press-office/2013/02/12/presidential-policy-directive-critical-infrastructure-security-and-resil (accessed: February 20, 2020). 
WH. 2018a. "Remarks by President Trump on the United States-Mexico-Canada Agreement." The White House, October 1, 2018; online: https:/www.whitehouse.gov/briefings-statements/remarks-president-trump-united-states-mexico-canada-agreement/ (accessed: February 20, 2020).

WH. 2018b. "President Donald J. Trump Launches a New Reciprocal Trade Relationship with the European Union." The White House, July 27, 2018; online: https://www.whitehouse.gov/briefings-statements/president-donald-j-trump-launches-new-reciprocal-trade-relationship-european-union/ (accessed: February 20, 2020).

WH. 2019. "Joint Statement of the United States and Japan." The White House, September 25, 2019; online: https://www.whitehouse.gov/briefings-statements/joint-statement-united-statesjapan-2/ (accessed: February 20, 2020).

Yu, Gu. 2018. "First Secretary Embassy of the People's Republic of China in the United States." Online: https://www.commerce.gov/sites/default/files/the_effect_of_imports_of_steel_on_ the_national_security_-_with_redactions_-_20180111.pdf (accessed: February 20, 2020).

Zawadzki, Sabina. 2019. "European Buyers of U.S. Gas Bristle at Terms." Reuters, May 3, 2019; online: https://www.reuters.com/article/us-europe-usa-lng-idUSKCN1S90NX (accessed: February 20, 2020).

Zeng, Ka. 2004. Trade Threats, Trade Wars. Ann Arbor: The University of Michigan Press. 